\title{
BØRNS RUM OG BEVAEGELSE PÅ VESTERBRO
}

Birgitte Justiniano | Christina Klyhs Albeck | Venka Simovska

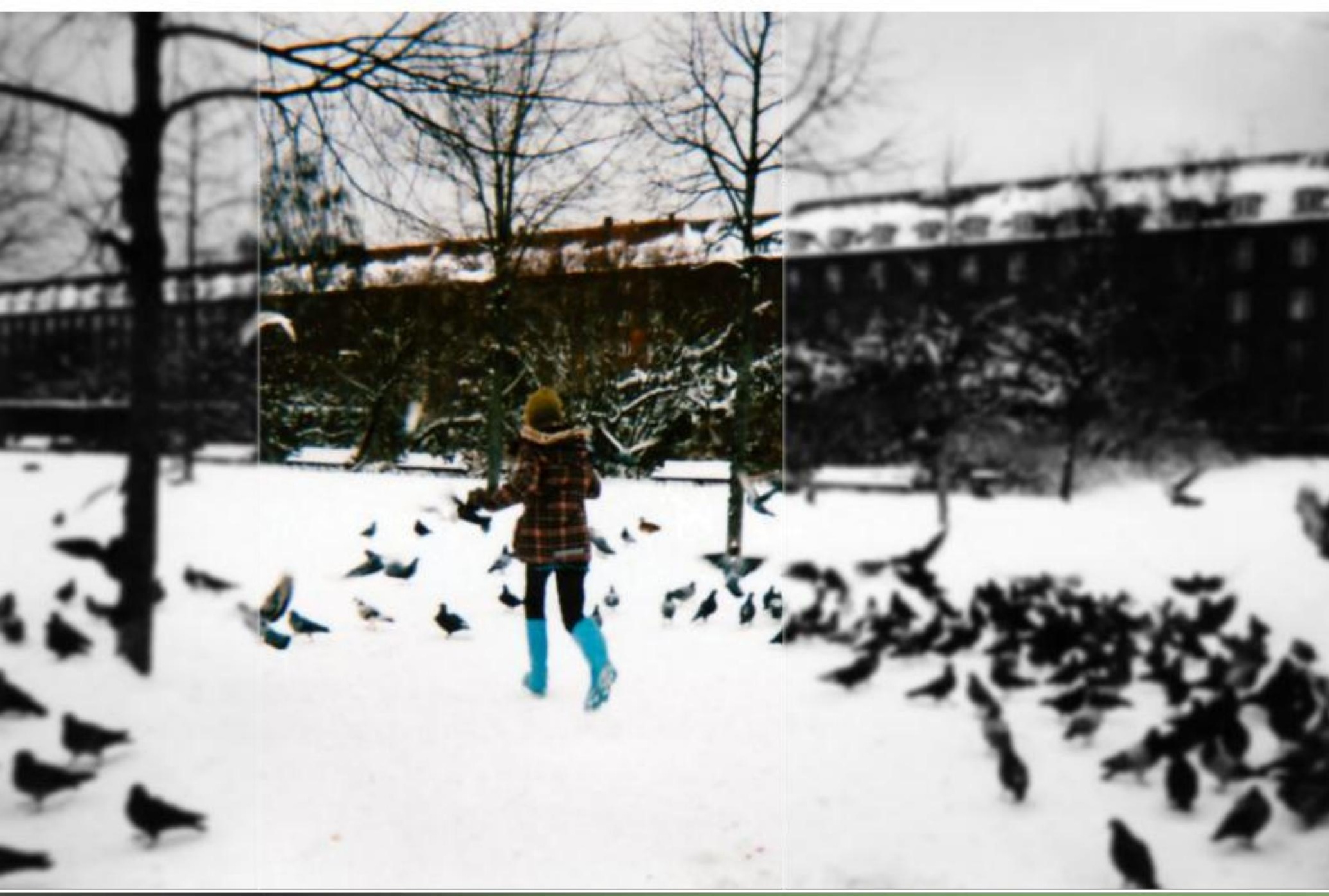

Forskningsprogram for Miljø- og Sundhedspædagogik

Danmarks Pædagogiske Universitetsskole, Aarhus Universitet

Sundhed, samfund, pædagogik og læering 


\section{Børns rum og bevægelse på Vesterbro}

Birgitte J ustiniano, Christina K. Albeck og Venka Simovska

Forskningsprogram for Miljø og Sundhedspædagogik Danmarks Pædagogiske Universitetsskole, Aarhus Universitet 


\section{Børns rum og bevægelse på Vesterbro}

Forskningsrapport, udarbej det for DGI-byens børne- og ungeprojekt Go-Active af:

Birgitte J ustiniano, Christina K. Albeck og Venka Simovska

Forskningsprogram for Miljø og Sundhedspædagogik, Danmarks Pædagogiske Universitetsskole, Aarhus Universitet, København, Danmark.

\section{DANMARKS PAEDAGOGISKE}

UNIVERSITETSSKOLE

AARHUS UNIVERSITET

Udgivet 2010

ISBN 978877430120 2; 978-87-7507-349-8 (elektronisk udgave)

DOI 10.7146/aul.78.72

Copyright @ DPU, Birgitte J ustiniano, Christina K. Albeck og Venka Simovska

Serie: Sundhed, samfund, pædagogik og læring, 2010:1

Serieudgiver: Forskningsprogram for Miljø og Sundhedspædagogik, Danmarks

Pædagogiske Universitetsskole, Aarhus Universitet

Layout: Leif Glud Holm

Korrektur: Hanne Frederiksen 


\section{Forord}

I denne rapport offentliggører vi resultaterne af en undersøgelse af børns og deres familiers oplevelse af og syn på deres muligheder for fysisk bevægelse på Vesterbro italesat i sprog og billeder. Undersøgelsen belyser børns og deres familiers egne oplevelser af eksisterende muligheder for idræt, leg og fysisk udfoldelse på Vesterbro. Undersøgelsens resultater giver et interessant indblik i, hvad der medvirker til at fremme eller hindre børns og deres familiers fysiske aktivitet i deres hverdag på Vesterbro.

Undersøgelsen er gennemført i tilknytning til 1. fase af DGI-byens børne- og ungeprojekt GoActive, der forløber i perioden medio 2009-2012 (www.dgi-byen.dk/go-active). Projektet har til hensigt at fremme fysisk aktivitet og trivsel for børn på Vesterbro med særlig fokus på de socialt udsatte. Kriterierne for projektet er fastlagt af Ministeriet for Sundhed og Forebyggelse og DGIbyen.

Rapporten er udarbej det af et forskningsteam bestående af forskningsassistent Birgitte J ustiniano, forskningsassistent Christina K. Albeck samt lektor Venka Simovska, der er forskningsprojektets leder. Leif Glud Holm har stået for rapportens layout.

God læselyst!

Venka Simovska

Forskningsleder

Forskningsprogram for Miljø og Sundhedspædagogik, Danmarks Pædagogiske Universitetsskole, Aarhus Universitet. 


\section{INHOLD}

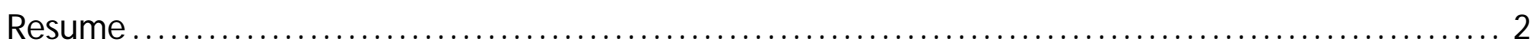

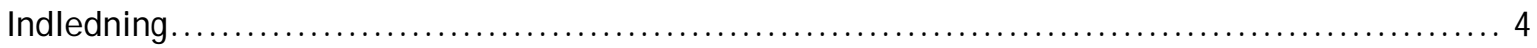

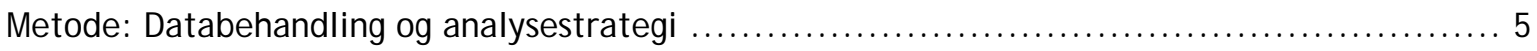

Analyse: Børn og deres familiers opfattelse af rum og fysisk aktivitet på Vesterbro: Tilgænge-

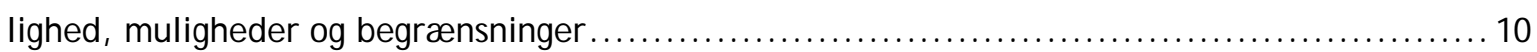

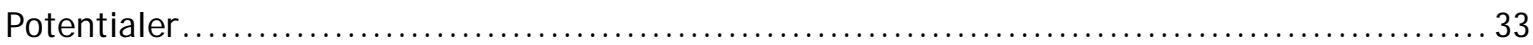

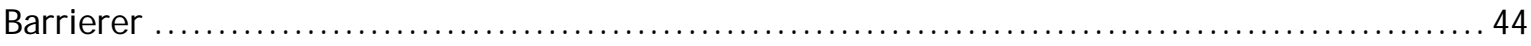

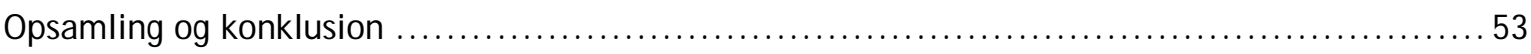

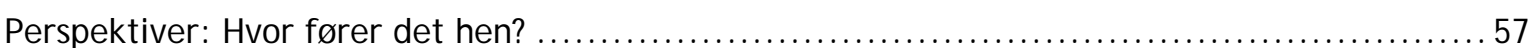

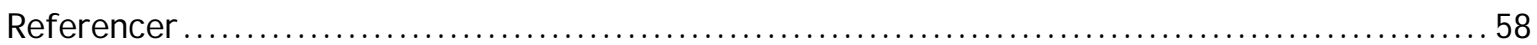




\section{Resume}

Denne rapport er resultatet af en undersøgelse af børns og deres familiers oplevelse af og syn på deres muligheder for fysisk bevægelse på Vesterbro italesat i sprog og billeder. Undersøgelsen er gennemført af Forskningsprogrammet for Miljø - og Sundhedspædagogik, Danmarks Pædagogiske Universitetsskole, Aarhus Universitet som et led i en forundersøgelse for DGI-byens børne- og ungeproj ekt Go-Active.

Undersøgelsen har til hensigt at belyse børns og deres familiers egne oplevelser af eksisterende muligheder for idræt, leg og fysisk udfoldelse på Vesterbro. Resultaterne fra undersøgelsen giver et interessant nyt indblik $\mathrm{i}$, hvad der medvirker til at fremme eller hindre børns og deres familiers fysiske aktivitet i deres hverdag på Vesterbro.

Gennem en analyse af børns og deres familiers opfattelse af deres muligheder for henholdsvis organiserede idrætstilbud og selv-organiserede fysiske aktiviteter, såsom spil og leg, indkredses hvilke forhold, der kan danne afsæt for tiltag i Go-Active-projektet med henblik på at fremme fysisk aktivitet blandt børn og unge på Vesterbro med særlig fokus på socialt udsatte.

Undersøgelsens resultater viser, at børn og deres familier er tilfredse med udbuddet af organiserede idrætstilbud, men at de samtidig har svært ved at gennemskue de mange aktivitetsmuligheder og afstemme dem i forhold til deres individuelle behov og forventninger. Børnene udtrykker stor tilfredshed med de organiserede aktiviteters form og indhold, særligt når de oplever, at instruktørerne giver dem mulighed for at tilegne sig aktiviteten eller spillet på en anerkendende og hensynsfuld måde. De selv-organiserede fysiske aktiviteter foregår såvel på offentlige legepladser som i parker og i gårdene. De offentlige steder ser ud til at være forbundet med en vis utryghed som følge af bydelens misbrugsmiljø, mens der generelt synes at være tryghed knyttet til gårdenes aflukkede rum og kendte mennesker. Gårdenes mindre kodede rum ser ligeledes ud til at kunne åbne for alternative og selv-organiserede samt kreative måder at bevæge sig på. Samspillet mellem rummets potentielle muligheder og den fysisk aktivitet (idræt, spil og leg) ser altså ud til at give forskellige muligheder for engagement og deltagelse.

Børns og familiers travle dagligdag ser ud til at være den væsentligste barriere for fysiske aktiviteter. Der synes at være en tydelig sammenhæng mellem børns skolemæssige, familiemæssige og trosmæssige pligter og deres overskud til fysisk aktivitet. Familierne giver udtryk for, at der er mangel på tid og overskud til fysisk aktivitet, og at de arbejdsmæssige og skolemæssige forpligtelser ofte må prioriteres frem for fysisk aktivitet og derved i sidste ende for deres sundhed.

Følgende synes at skabe barrierer for børn og deres familiers fysiske bevægelse:

- Utryghed knyttet til forskellige steder på Vesterbro som følge af misbrugsmiljøer

- Træthed og tidsmangel som følge af børns huslige, skole - og trosmæssige pligter 
Til gengæld synes der at være et særligt potentiale at hente i gårdmiljøernes rum og de lege, spil og andre fysiske aktiviteter, som børn trods deres træthed og mangel på tid udfolder der. Gårdenes mindre organiserede og trygge rum ser ud til at udgøre et særligt potentiale for børns mulighed for at udfolde sig fysisk og kreativt.

Rapporten konkluderer, at rummet bør inddrages som en pædagogisk faktor. Ved at medtænke denne rumlige faktor skabes der mulighed for at reflektere over rums kulturelle medbetydninger, der er indbygget i børns og voksnes kulturelle forforståelse og derfor også deres valg af fysisk aktivitet og visioner i relation til udvikling af aktivitetstilbud. Ved at medtænke dette vil det $\mathrm{i}$ højere grad blive muligt at tilrettelægge tilbud, der rumligt både understøtter mere strukturerede aktiviteter så som traditionelle former for sport og spil, men også kreative og mere uorganiserede fysiske udfoldelser og lege, der kan udvikles af og med børn som aktive deltagere.

På baggrund af undersøgelsens resultater anbefales det at inddrage både børn og deres familier og skolerne i bydelen i planlægningen af nye tiltag for at fremme fysisk aktivitet i DGI-byens børne- og ungeprojekt Go-Active. Ved at inddrage skolerne kan der dæmmes op for børns mentale træthed ved at koble læringsprocesser med fysisk aktivitet i skoletiden. Rollespillets form og struktur kunne være et godt bud på en pædagogisk ramme for læreprocesser, hvor børn ikke bare opnår en vis grad af medbestemmelse, men inviteres til ægte deltagelse (jf. Simovska, 2006).

Rapporten anbefaler, at der ved etablering af fremtidige fysiske aktivitetstilbud tages højde for følgende:

Tryghed:

- At skabe gode samspil mellem rum og aktiviteter, hvor tryghed er i fokus, svarende til gårdmiljøernes trygge atmosfære, og en vis form for voksenstyring, der ikke resulterer i for megen kontrol og overvågning, som børnene oplever hæmmende for deres kreativitet og selv-organiserede spil og leg.

Involvering:

- At skabe rum og rammer for, at børn kan inkluderes som aktive deltagere i planlægning og udførelse af den fysiske aktivitets indhold og form, som en både kropslig og mental læreproces.

Tid:

- At der tages hensyn til børns skole-, tros- og familiemæssige pligter. Der bør indledes et samarbejde med skolerne og bydelens foreninger knyttet til trossamfund for herved at skabe fysiske aktivitetstilbud, der matcher børns tid og overskud til at bevæge sig. 


\section{Indledning}

Denne rapport redegør for den forundersøgelse, som Forskningsprogrammet for Miljø- og Sundhedspædagogik ved Danmarks Pædagogiske Universitetsskole, Aarhus Universitet, har gennemført i tilknytning til 1. fase af DGI-byens børne- og ungeproj ekt Go-Active, der forløber i perioden medio 2009-2012. Projektet har til hensigt at fremme fysisk aktivitet og trivsel for børn på Vesterbro med særlig fokus på de socialt udsatte. Kriterierne for projektet er fastlagt af Ministeriet for Sundhed og Forebyggelse og DGI-byen ${ }^{1}$ (se evt. www. dgi-byen. dk/ go-active).

Forskningsprogrammet for Miljø- og Sundhedspædagogik har i denne forundersøgelse haft til opgave at undersøge børns og familiers viden om og brug af rum og tilbud for fysisk aktivitet på Vesterbro, samt hvilken betydning dette har for deres fysiske aktivitet, engagement og deltagelse.

Fire skoler på Vesterbro: Vesterbro Ny Skole (VNS), Tove Ditlevsens Skole (TDS), Oehlenschlægersgades Skole (ØS) og Engskolen (ES) har været behjælpelige med at etablere kontakt til børn og deres familier med henblik på interview og fotoregistrering. Undersøgelsen har samlet haft kontakt til 24 børn og 6 af disses familier.

Forundersøgelsen har haft til hensigt at belyse børns og deres familiers egne oplevelser af eksisterende muligheder for idræt, leg, spil og anden fysisk udfoldelse på Vesterbro. Børn og deres familier har gennem fotos og interview bidraget med deres personlige beretninger om, hvilke eksisterende muligheder for fysisk bevægelse, de opfatter, at de har, og hvad de eventuelt kunne forestille sig af nye tiltag, der kan bidrage til at øge deres fysiske aktivitet i hverdagen. Der har været lagt vægt på at belyse, om børn og deres familier oplever begreberne 'deltagelse' og 'engagement' som betydende for deres fysiske aktivitet.

Børns og familiers viden om eksisterende idrætstilbud på Vesterbro ekspliciteres og analyseres ud fra interview og fotos og det belyses, hvilke ønsker og behov de synes at have for at øge deres fysiske aktiviteter. Denne viden kan bidrage til nytænkning af eksisterende tilbud og give ideer til alternative bud på fysisk aktivitet, som DGI-byens børne- og ungeprojekt kan drage fordel af.

Rapporten er opdelt i tre dele: en gennemgang af undersøgelsens formål, design og metode, en analyse af og sammenfatning af data samt en konklusion og en præsentation af de perspektiver, der opstår på baggrund af undersøgelsens resultater.

\footnotetext{
${ }^{1}$ Go-Active er DGI-byens børne- og ungeproj ekt, som sigter mod at fremme fysisk aktivitet og trivsel for børn på Vesterbro med særlig fokus på de socialt udsatte. (DGI-byen, 2009).
} 


\section{Undersøgelsens formål}

Forundersøgelsen har ud fra et hverdagsperspektiv søgt at skabe indsigt i børns og deres familiers oplevelse af eksisterende muligheder for idrætstilbud på Vesterbro samt deres oplevelse af disses tilgængelighed og dettes betydning for deres engagement. Derudover ses der på, hvilke mere generelle tilbud for fysisk aktivitet, som børn og deres familier oplever, at områdets legepladser, parker og private gårde tilbyder dem.

Tre forhold ved børns og deres familiers fysiske aktivitetsadfærd belyses:

- Kendskab til eksisterende, organiserede idrætstilbud (strukturelle og sociale aspekter) på Vesterbro, og hvilken betydning det har for deres aktuelle fysiske aktivitet

- Kendskab til og brug af legepladser, parker og pladser på Vesterbro til selv-organiserede fysiske aktiviteter med familie og venner, samt hvilken betydning det har for deres aktuelle fysiske aktivitet

- Betydningen af forskellige former for deltagelse og involvering for børn og deres familiers engagement, lyst og motivation i forhold til fysisk aktivitet.

\section{Metode: Databehandling og analysestrategi}

Undersøgelsens design er bygget op som en triangulering af interview med børn i fokusgrupper, børns fotoregistreringer og familieinterview. Ønsket har været at få indblik i og forstå børns og deres familiers egne perspektiver på deres hverdags betingelser.

\section{Metodedesign og udvælgelseskriterier}

Hovedinformanterne i undersøgelsen er børn og i mindre omfang deres familier. Undersøgelsen har anvendt fokusgruppeinterview med børn, fotoregistrering og familieinterview. Fokusgrupperne er sammensat med hjælp fra lærere på de enkelte skoler og ud fra kriteriet om maksimum variation (jf. etnicitet, sociale ressourcer, køn, alder samt omfang af jævnlig fysisk aktivitet). 


\section{Undersøgelsen har bestået af:}

\section{- Fokusgruppeinterview med børn:}

2 grupper af 3 børn på i alt 3 skoler og 1 gruppe på 6 børn på 1 skole (dvs. 6 børn på hver skole). I alt er 24 børn blevet interviewet. Fokusgruppeinterviewene har haft til hensigt at belyse børns kendskab til og brug af idrætsforeninger samt andre mindre organiserede tilbud og rum på Vesterbro. Herefter er der i hver fokusgruppe - i samråd med lærer - blevet indkredset 1 barn, som er blevet bedt om at tage fotos af steder og aktiviteter. Dette barns familie har herefter deltaget i familieinterview.

\section{- Fotoregistrering:}

Bestående af 6 udvalgte børns fotoregistreringer. Eleverne blev bedt om over fire dage at tage fotos af samspil mellem deres omgivelser og deres fysiske aktiviteter herunder idræt, spil og leg med kammerater og med familie. Fotometoden er inspireret af Morrow (2004) og argumentet for brug af fotos som oplæg til et efterfølgende interview har været, at fotos' ordløse sprog synes at kunne berige interviewets sproglige form (Rasmussen K., 2002:10).

\section{- Familieinterview:}

Der blev i alt gennemført 6 familieinterview, hvor fotografierne er blevet inddraget som visuelle ytringer og selvstændige fortællinger, der kan supplere, bidrage til og understrege interviewets sproglige ytringer (Rasmussen, K., 2002). Børnene har herved haft mulighed for at ytre sig på to måder: gennem billeder og ord.

Fokusgruppeinterview er blevet organiseret $\mathrm{i}$ et samarbejde mellem DGI-byens projektleder, en række kontaktpersoner (lærere) på skolerne og forskerne. Fokusgruppeinterview med børn er blevet gennemført på skolen i skoletiden, mens familieinterviewene er blevet gennemført i hjemmet ${ }^{2}$. Projektet og skolernes kontaktpersoner har været behjælpelige med at sikre skolernes støtte i forhold til at overholde etiske regler, fx samtykkeerklæring fra forældre.

\section{${ }^{2}$ Udvælgelseskriterier:}

Gennem hele undersøgelsesprocessen er de omtalte udvælgelseskriterier søgt opfyldt. I forhold til fotoregistrering og familieinterview er overvejende børn af ressourcestærke familier - indkredset i samråd med lærere på de enkelte skoler - blevet bedt om at deltage for at sikre undersøgelsens gennemførsel det mindre antal fotoregistreringer og familieinterview taget i betragtning. Opfattelsen har været, at disse børn har haft lettere ved at administrere den meget selvstændige og krævende opgave, det er at tage fotos over flere dage og efter instruks. Dette har medført, at der har deltaget en overvægt af ressourcestærke børn i undersøgelsens fotoregistrering og familieinterview, hvorved undersøgelsen ikke fuldt ud lever op til de oprindelige udvælgelseskriterier.

Fotodata: Under undersøgelsesprocessen er brugen af engangskameraer ligeledes blevet ændret til brug af børnenes egne mobiltelefoner, idet dette visuelle medie har syntes at fungere bedre for børnene. Ved brug af engangskameraer har børnene ikke umiddelbart kunnet se resultatet af det foto, de har taget, hvilket har medført, at en hel del fotos er gået tabt på grund af dårlig belysning, skæve perspektiver ol. Tre film ud af seks har været ubrugelige, og kun ca. 60 fotos har været anvendelige. Efter udskiftning af engangskamera til mobiltelefon har 4 børn bidraget med yderligere 40 anvendelige fotos, dvs. i alt omkring 100 anvendelige fotos. Mange af fotoene har været gentagelser. De bedste er derfor udvalgt til at beskrive børns oplevelser af steder for fysisk aktivitet på Vesterbro. Kun 3 børn har afleveret de tilhørende sproglige refleksioner. Dette er søgt opvej et af emner i familieinterview. 
Triangulering som metode har med de forskellige datakilder givet mulighed for at analysere, diskutere og vurdere børnenes og deres familiers forskellige ytringer og oplevelser i forhold til fysisk aktivitet. Fokusgruppeinterviewene har ved sin form givet børnene en særlig mulighed for at kommentere og stille spørgsmål til samt diskutere hinandens fortællinger. Ved at spørge ind til børns umiddelbare oplevelser af deres omgivelser og muligheder for fysisk aktivitet er det forsøgt at fremme en reflekteret fortolkning af deres oplevelser.

\section{Barnet som kompetent informant}

Barnet betragtes som den kompetente informant, der ud fra et hverdagslivsperspektiv, iagttager egne muligheder for fysisk bevægelse og aktivitet $\mathrm{i}$ forskellige fysiske omgivelser. Fokus har været på relationerne mellem fysisk bevægelse og fysiske rum, samt hvilken betydning dette relationelle samspil har for børns og deres familiers oplevelse af muligheder for at deltage i og selv skabe rum for fysiske aktivitet.

Børnenes fotografier betragtes som visuelle ytringer og selvstændige fortællinger på lige fod med det talte ord (Rasmussen, K, 2002). Børnene har gennem fotometoden og tre tilhørende iagttagelsestemaer fået mulighed for at visualisere og fastholde rummenes kulturelle betydning for fysisk bevægelse - både som organiserede og selv-organiserede fysisk aktiviteter.

Tesen er, at børn er kompetente informanter, og at koblingen mellem interview og fotos giver dem en særlig stemme, hvorved børnene har fået mulighed for at være med til at præge resultatet af undersøgelsen.

\section{Analysestrategi}

I det følgende præsenteres begrundelser for valg af analytiske opdelinger og databehandling. Det beskrives og begrundes, hvordan undersøgelsen forstår forholdet mellem rum og bevægelse, og hvorledes børns og familiers egne iagttagelser er særligt kompetente bidrag til forståelse af deres engagement og motivation i forhold til idræt, spil og leg.

\section{Rum og bevægelse}

Fysisk bevægelse kan ikke ses uafhængigt af de fysiske omgivelser, den er indlejret i, men må opfattes som bevægelse, der opstår $i$ et dynamisk samspil mellem menneske og rum. Med begrebet 'omgangskvaliteter' (Gibson, 1979) bliver børns og deres familiers fysiske aktiviteter iagttaget som et samspil mellem det konkrete sted, hvor de foregår - dvs. geografisk placering - $\mathrm{i}$ en idrætsklub, en offentlig (lege)plads etc., og den medfølgende kultur, der hersker her, fx regler for fysisk og social adfærd (Flensborg, 2009:42). Det iagttages desuden, hvem børnene henter 
deres inspiration fra, fx venner, familie og klassekammerater, når de vælger idrætsform eller anden fysisk aktivitet.

\section{Tre analytiske iagttagelsestemaer: Kulturelt blik på børn, rum og bevægelse}

Tre analytiske iagttagelsestemaer er valgt for at kunne skelne mellem børns muligheder for organiserede idrætsaktiviteter (foreningsidræt), deres selv-organiserede fysiske aktiviteter som spil og spontan leg og mellem organiserede rum og selv-organiserede rum. I undersøgelsen bliver børnene ud fra disse tre iagttagelsestemaer bedt om at visualisere og verbalisere deres umiddelbare oplevelser af og muligheder for:

- Idrætsaktiviteter (foreningsidræt) i organiserede fysiske rum og dets betydning for børns motivation og engagement

- Fysiske aktiviteter (selv-organiseret spil) i organiserede rum og dets betydning for børns motivation og engagement

- Fysiske aktiviteter (selv-organiseret spontan leg) i selv-organiserede rum og dets betydning for børns motivation og engagement.

På den baggrund undersøges de fysiske rums tilbud med deres muligheder og begrænsninger, der får betydning for børns interaktion som henholdsvis 'bruger' og 'aktiv medskaber' af de fysiske aktiviteter og de fysiske omgivelser. Undersøgelsen sætter fokus på, hvilke fysiske rum der giver børn mulighed for forskellige aktiviteter (motion, spil, leg), og hvad forskellige rum signalerer via form, funktion og regler som det samlede sæt af faktorer, der influerer på børns interaktionsmuligheder.

Antagelsen har været, at samspillet mellem rum og aktiviteter (idræt, spil og leg) skaber forskellige muligheder for deltagelse og engagement i forhold til fysiske udfoldelsesmuligheder. Analysen af dataene blev gennemført over tre trin (jf. J ens Rasmussens operative, konstruktivistiske hermeneutik (2002), hvorved det er søgt, at (gen)finde den oprindelige mening i sproglige såvel som visuelle ytringer. 


\section{Analysetrin:}

Der blev foretaget en tematisk iagttagelse af interview og foto med henblik på en kategorisering i forhold til den overordnede problemstilling. Konkret har det haft til formål at trække visuelle og sproglige udsagn ud af materialet jf. analysetemaerne (se analytiske iagttagelsestemaer).

\section{Analysetrin:}

De (gen)iagttagede iagttagelser er blevet anvendt til at gennemføre en analyse ud fra de analytiske iagttagelsestemaer. Der er foretaget en fortolkning af de udvalgte generaliseringer jf. den overordnede problemstilling.

\section{Analysetrin:}

På baggrund af trin 1 og 2 er der på tredje analysetrin skabt grundlag for en opsummering af undersøgelsens resultater.

Analysen af undersøgelsens data er blevet gennemført med baggrund $\mathrm{i}$ analysestrategiens tre iagttagelsestemaer for herved at opnå viden om børns og deres familiers opfattelse af deres muligheder for organiserede såvel som selv-organiserede fysiske aktiviteter. Med begrebet omgangskvaliteter er der skelnet mellem fotoenes umiddel bare beskrivelser af de fysiske omgivelser fx fodboldbaner og gyngestativer, der indbyder til helt bestemt brug, og de kulturelle medbetydninger som viser sig i den måde, hvorpå børn vælger at bruge steders funktionalitet. Opfattelsen er, at børns intuitive fotoperspektiv afspejler en umiddelbar sanselig iagttagelse, som er præget af deres egen kulturelle forforståelse, der kommer til udtryk i billedet i form af temavalg, symboler og lyssætning, men mest af alt i dets vinkel. Børns fotoregistreringer kan derfor defineres som særlige æstetiske beskrivelser, der er båret af en sanselig iagttagelse og fortolkning. Analysen har forholdt sig til fotografiernes umiddelbare visuelle meddelelsesform og deres tilknyttede sproglige ytringer. Gennem interviewet har de visuelle ytringer kunne uddybes, hvorved børns mulighed for fysisk bevægelse i forskellige rum kunne fortolkes.

Det har været et ønske herigennem at belyse børns og familiers kendskab til idrætstilbud, deres brug af disse og at indkredsesærlige, udvalgte fysiske rum (parker, pladser, legepladser etc.) på Vesterbro, der af børn og familier bliver betragtet som attraktive rum for deres selv-organiserede fysiske aktiviteter: spil og leg. Ligeledes har det været et ønske at få belyst, om der er fysiske områder, der i særlig grad er blevet fravalgt fx pga. utryghed, eller om der eksisterer andre former for begrænsninger $\mathrm{fx}$ skolemæssige og familiemæssige.

Herved opnås viden om børns og deres familiers opfattelse af fysiske aktiviteters tilgængelighed, muligheder og begrænsninger. 


\section{Analysens fem temaer}

Undersøgelsens analyse præsenteres i følgende fem temaer:

\section{Rum, idræt og deltagelse}

(organiseret idræt i organiserede rum)

\section{Rum, spil og sikkerhed}

(selv-organiseret fysisk aktivitet i organiserede rum)

\section{Rum, leg og regler - kreativitet}

(selv-organiseret leg i organiserede og uorganiserede rum)

\section{Potentialer: Rum der fremmer fysisk aktivitet}

(ikke-organiserede rum og delvis autonomi)

\section{Barrierer for fysisk aktivitet}

Tid: Skolemæssige og religiøse forpligtelser

Denne del følges op af en egentlig opsamling og vurdering af resultaterne med fokus på rum og aktiviteters tilgængelighed og betydningen heraf for børns og familiers engagement og motivation i forhold til fysisk aktivitet.

\section{Analyse \\ Børns og deres familiers opfattelse af rum og fysisk aktivitet på Vesterbro: Tilgængelighed, muligheder og begrænsninger}

Analysen bygger på børns og familiers perspektiver på fysiske aktiviteters tilgængelighed beskrevet $\mathrm{i}$ fotos og interview. Gennem fem kapitler præsenteres de fem nævnte temaer: 1) Rum, idræt og deltagelse, 2) Rum, spil og sikkerhed, 3) Rum, leg og regler/kreativitet, 4) Potentialer: Rum der fremmer fysisk aktivitet, 5) Barriere: Tid der hæmmer fysisk aktivitet.

\section{Rum, idræt og deltagelse}

Dette afsnit belyser børns og familiers kendskab til idrætstilbud på Vesterbro og deres mulighed for indflydelse på disse tilbud. I afsnittet belyses børns og familiers organiserede idrætsaktiviteter (foreningsidræt) i organiserede rum og dets betydning for børns motivation og engagement jf. det analytiske iagttagelsestema. 


\section{Børns og familiers kendskab til og brug af idrætstilbud}

Langt de fleste af de interviewede børn fra de udvalgte skoler på Vesterbro går eller har gået til forskellige former for idræt og sport organiseret $\mathrm{i}$ foreninger overvejende på Vesterbro. En del drenge såvel som piger dyrker fodbold, flamencodans, thai- og kick boksning, bordtennis, dans, taekwondo, svømning, springgymnastik, badminton, fitness eller volleyball. Særligt fodbold, thai- og kick boksning synes at være populært blandt begge køn.

I flere tilfælde går de interviewede til foreningsorganiseret idræt eller sport uden for Vesterbro. En del af de interviewede børn og familiemedlemmer nævner, at de er tilmeldt idrætstilbud i andre kommuner, heriblandt roning, undervandsrugby, ridning, kung fu, parkour, rollespil eller tennis. De interviewede børn omtaler sjældent ved navn de foreninger, de er engagerede i, De refererer oftest til, at 'de går til' en aktivitet og så det sted eller lokalområde, hvor foreningerne har til huse, fx 'i DGI-byen' eller 'i Enghave'.

De interviewede børn finder primært ud af, hvad de gerne vil engagere sig i af foreningsorganiserede idrætsaktiviteter via deres venner og kammerater. De får ideer og bliver inspirerede enten ved at høre om venners og kammeraters oplevelser eller ved at tage sammen med dem til aktiviteten, hvilket i flere tilfælde har resulteret i, at de har valgt at begynde at dyrke aktiviteten selv. De interviewede mener ikke selv, at deres familie spiller en særlig stor rolle i forhold til valg af foreningsorganiseret idræt - ligesom de også sjældent går til organiseret idræt sammen med deres forældre eller søskende. Nogle børn fortæller dog, at deres søskende eller kusiner og fætre inspirerer dem i valg af aktivitet. Kusiner og fætre nævnes dog oftest af børn af anden etnisk oprindelse end dansk, og sandsynligvis oplever de deres fætre og kusiner som både familie og venner. Et par af de interviewede børn nævner, at de også inspireres til valg af foreningsorganiseret aktivitet i fritidshjemmet og klubben. Her får de mulighed for at afprøve forskellige former for sport og spil, som det er muligt at dyrke i foreninger på Vesterbro. Nogle af de ældre børn mener, at det at lade sig inspirere til at vælge idrætsaktivitet af venner og ikke af familie også er relateret til en aldersmæssig orientering mod venner.

"Min bonusfætter går til badminton og hans mor er også en rigtig god badmintonspiller, og så prøvede jeg at spille med ham på en tur til Sverige og så syntes jeg, det var sjovt og startede"

(S, dreng 6. klasse, ØS, fokusgruppeinterview, 27-01-2010)

"En fra min klasse, som jeg er tæt på, skulle starte til badminton og S. gør det jo også, og så valgte jeg at starte med dem"

( , pige 6. klasse, ØS, fokusgruppeinterview, 27-01-2010)

"En af mine venner gik til fodbold, og så ville jeg også gerne prøve det"

( $P$, pige 4. klasse, ES, fokusgruppeinterview, 11-01-2010) 
De fleste af de interviewede har jævnligt skiftet deres idrætsform ud af forskellige grunde. Enten fordi aktiviteten syntes for kedelig og ensformig, for krævende, for dårlig en oplevelse eller fordi børnene ikke syntes, at der skete en udvikling, således at de blev bedre til den pågældende sport - enkelte gange har det været for svært at starte til aktiviteten, fordi børnene er startet midt i en sæson. Citaterne fra interviewene nedenfor demonstrerer dette tydeligt.

En pige beskriver, at hun gik til springgymnastik i seks år uden egentligt at udvikle sine sportslige kompetencer, hvorved hun mistede lysten til idrætstilbuddet:

"J eg gik til spring i seks år, men jeg blev aldrig rigtig god til det, og så havde jeg ikke rigtig lyst til det, der skete ikke en udvikling, så jeg havde ikke lyst til at fortsætte"

(J , pige 6. klasse, ØS, fokusgruppeinterview, 27-01-2010)

En anden pige beskrev en danseundervisning som for krævende, hvilket medførte at hun holdt op:

"Til sidst syntes jeg, det begyndte at blive kedeligt, det begyndte med, at jeg ikke kunne huske dansetrinene, jeg kunne ikke finde ud af det og stod hele tiden bagerst, fordi jeg ikke kunne finde ud af det"

(Al, pige 5. klasse, VNS, fokusgruppeinterview, 13-01-2010)

En tredje fandt bordtennis for kedeligt og uden de rette udfordringer og thai dans for krævende, idet det blev forventet, at man jævnligt deltog i opvisninger:

"J eg synes bare, at det der bordtennis var kedeligt, men så har jeg glemt, at jeg også har gået til sådan noget thai dans"

(E, pige 4. klasse, ØS, fokusgruppeinterview, 27-01-2010)

"Thai dans?"

(interviewer)

"J a, sådan noget rigtig svært noget, jeg lærte ikke så meget, og så skulle man til opvisning hele tiden!"

(E, pige 4. kl., ØS, fokusgruppeinterview, 27-01-2010)

En fjerde stoppede i en fodboldklub, fordi han fandt det ubehageligt og nedværdigende, da han blev holdt udenfor og behandlet dårligt af de andre deltagere: 
"Hvordan kan det være, du har skiftet klub?"

(interviewer)

"Fordi den klub, SSB, som jeg gik i, var jeg ikke særlig glad for, der var aldrig nogen som spillede mig og så var der også nogle drenge, som var onde mod én og sådan, så jeg skiftede til den klub, jeg går i nu"

(N, dreng 5. klasse, VNS, fokusgruppeinterview, 13-01-2010)

De ovenstående citater vidner om, at de interviewede børn har meget blandede erfaringer med idrætstilbud på Vesterbro. I nogle tilfælde starter børn på aktiviteter og dropper ud. Årsagen til dette ser ikke ud til at handle om idrætstilbuddets indhold, men snarere om formen og det sociale miljø, det foregår i.

Generelt har de interviewede børn et stort kendskab til de mange forskelligartede idrætstilbud på Vesterbro, men børnenes udtalelser vidner om, at det kan være svært at finde den helt rette aktivitetsform, der passer lige netop til den enkeltes behov og forventning. En situation, der i familieinterviewene bekræftes af en mor til en dreng på 12 år. Denne mor udtrykker, at hun oplever, at der er rigeligt med idrætstilbud på Vesterbro, men at hun har svært ved at overskue de muligheder, der er, og hvad der er det rette tilbud for hendes børn:

"Men jeg synes faktisk, det har været svært nogen gange, hvad kunne være fedt at gå til, vi forsøgte med noget springgymnastik, det er lidt svært at gennemskue, hvad der egentlig lige er af tilbud og hvis man vil gå til et eller andet, som er meget populært fx svømning eller noget så skal man jo stå i kø, og det var virkelig sådan noget med, hvor man stod i køen og man følte sig virkelig, yes, vi har vundet, vi har fået en plads på et svømmehold og sådan noget, ikke?"

(Mor til S, dreng på 12 år, ØS, familieinterview, 11-02-2010)

Det ser overordnet ud til, at børn og forældre har et bredt kendskab til og god erfaring med idrætstilbud på Vesterbro, men samtidig at det kan være svært at overskue de mange muligheder og frem for alt at finde det helt rette tilbud, der passer til deres individuelle behov og forventninger.

\section{Børn og deres familiers mulighed for indflydelse som deltagere i idrætstilbud}

Langt de fleste interviewede børn udtrykker intet ønske om større medbestemmelse i de idrætstilbud, de deltager i. Derimod ser det ud til, at der er et gennemgående ønske om at blive behandlet med respekt og som ligeværdig af instruktør og andre deltagere for at føle sig velkommen 
I interviewene med børnene og deres familier møder vi en dreng (N). $\mathrm{N}$ går til fodbold i klubben Vestia, som træner en gang om ugen i DGI-byen om vinteren og to gange om ugen i Bavnehøj Idrætsanlæg om sommeren. $\mathrm{N}$ har meldt sig til at fotoregistrere sine fysiske aktiviteter og de rum, han udfører dem i. Fotoene nedenfor (foto $1 \& 2$ ) viser en almindelig træningsaften $i$ en helt almindelig sportshal. Man kan sige, at de fysiske omgivelsers direkte omgangskvalitet er, at de er funktionelle og egner sig til fodboldspil. Rummet er stort, og der er højt til loftet.

En sportshal indeholder desuden en række indirekte kulturelle koder af normer for kulturel adfærd. Dens indirekte kvalitet signalerer, at det fx er i orden at larme, skyde hårdt til bolden og til dels råbe ad hinanden. Dette matcher sportshallens førnævnte direkte omgangskvalitet, der netop indbyder til fodbold og ikke til eksempelvis meditativ dans.

\section{Foto 1}

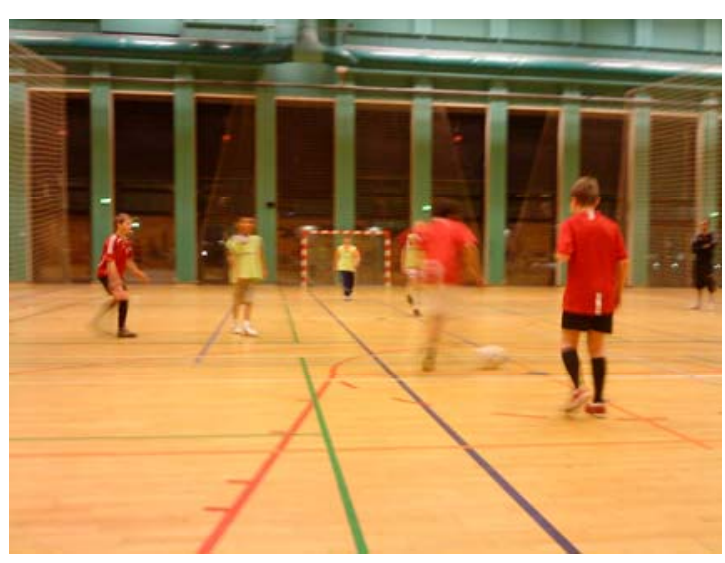

Foto af fodboldtræning i klubben Vestia der om vinteren træner i DGI-byen (om sommeren i Bavnehøj).

\section{Foto 2}

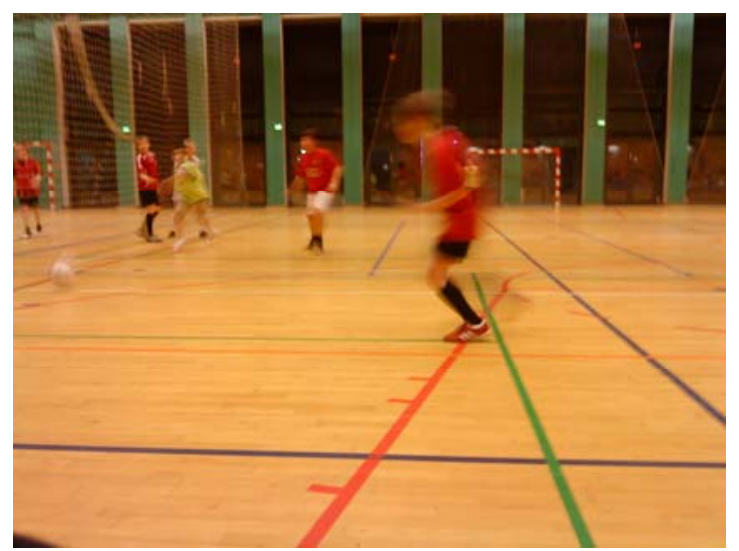

Foto: N, dreng på 12 år, VNS, Familieinterview, 04-02-2010

Rummet såvel som aktiviteten appellerer til en høj grad af fysisk aktivitet med en kollektiv orden, der indikerer, hvilke roller hver især har i dette spil. Dette appellerer måske netop til en særlig form for deltagelse. $\mathrm{N}$ fortæller, at han til fodbold kun deltager som spiller og ved at tage målene ind og ud igen efter endt træning. $\mathrm{N}$ er godt tilfreds med denne form for deltagelse frem for at være aktiv medskaber af de fysiske aktiviteter, som han er en del af. $\mathrm{N}$ har ikke tænkt yderligere over sin egen rolle som deltager $\mathrm{i}$ fodboldklubben og accepterer tilsyneladende form, struktur, regler og rollefordeling.

$\mathrm{N}$ nævner dog, at han til fodbold af og til giver udtryk for ønsket om ændring i træningsformen, når træningen synes for ensformig. Han fortæller, at han er lidt træt af, at de altid spiller kamp, 
og at han derfor indimellem søger indflydelse ved at italesætte sin utilfredshed og herved opnå en vis form for medbestemmelse.

"Vi spiller kamp ved hver eneste træning det er jeg lidt træt af, at vi altid gør, så kan man bare lige gå, så nogen gange går vi bare lige over for at sige; kan vi ikke lave noget træning hvor vi løber frem og tilbage eller et eller andet?"

(N, dreng på 12 år, VNS, familieinterview, 04-02-2010)

Og videre:

"Hvis de ligesom kan mærke, at nu er den sivet ind, at man kan spille i en trekant og sådan noget og alt sådan noget forskelligt, så kan vi ligesom godt være med til at bestemme lidt selv"

(N, dreng på 12 år, VNS, familieinterview, 04-02-2010)

Man kan altså tale om deltagelse i en indirekte form i den organiserede idrætsaktivitets struktur.

Direkte indflydelse ser ikke ud til at være prioriteret af børnene, når de er engageret i organiseret sport. Til spørgsmålet om N kunne ønske sig at få lov til at bestemme lidt mere, svarer han meget resolut:

"Nej, så kommer det til at gå helt i hat og briller"

(N, dreng på 12 år, VNS, familieinterview, 04-02-2010)

Mener du ikke, I ville kunne administrere det?

(interviewer)

"Nej, vi er snart tolv år alle sammen, men jeg tror alligevel, det ville alligevel gå lidt galt"

(N, dreng på 12 år, VNS, familieinterview, 04-02-2010)

"Men du kan godt lide det, som det er?"

"Ja"

(interviewer)

(N, dreng på 12 år, VNS, familieinterview, 04-02-2010)

Hans opfattelse er altså snarere, at en aktiv deltagelse vil virke hæmmende på det samlede fysiske aktivitetstilbud, som han kommer for at dyrke. N's tiltro til at kunne udøve og administrere medbestemmelse i idrætssammenhænge ser således ud til at være temmelig lav.

Manglende ønske om aktiv deltagelse kan genfindes i forældrenes engagement i deres børns idrætsaktivitet. Både N's mor og Ans mor (hvis søn ligeledes går til fodbold i Vestia) giver udtryk for, at de er godt tilfredse med ikke at skulle deltage mere aktivt i deres sønners fodboldtræning. Deres deltagelse er 'begrænset til' at bakke op om aktiviteten som heppende tilskuere på sidelinjen og til at deltage $i$ et mindre antal sociale arrangementer. Ingen af mødrene ytrer på 
nogen måde ønske om at deltage mere aktivt eller søge indflydelse i selve træningen. En af mødrene udtrykker det således:

"Vi er ikke meget aktive. Selvfølgelig er det sådan, at når børnene skal spille kamp, så puljer man de børn, der skal med i de biler, der er, så en gang imellem har vi en finger med, men vi er ikke dem, der vasker trøjer"

(N's mor, VNS, familieinterview, 04-02-2010)

Forældrene giver udtryk for, at de oplever, at deres børn er glade for den måde, som det foregå på. En mor fortæller, at hendes søn er meget tilfreds, og hun oplever, at trænerne har forståelse for, at hende søn indimellem er træt efter en lang dag.

"Han er tilfreds, først de varmer op 5 -10 min. Og så begynder de at spille. J eg tror, han er tilfreds. Men han godt sige, hvis han er træt, de forstår børn godt. De har ikke problemer der"

(Ans mor, ES, familieinterview, 20-01-2010)

Ud fra børns og forældres udsagn synes der at være en stor tilfredshed med idrætstilbuddenes meget styrede og strukturerede form. Forventningen er, at man får noget og ikke selv skal yde noget ud over den umiddelbare sportslige præstation. De oplever, de får det, de kommer der for: et konkret sportsligt udbytte. Både børn og deres familier er tilsyneladende tilfredse med ikke at skulle bidrage yderligere i de organiserede tilbud. Der ser ud til at være en klar sammenhæng mellem den generelle forventning til idrætstilbud som helhed, og det udbytte som børn og forældre synes, de får. De organiserede og strukturerede idrætstilbud ser således ud til - i såvel form, indhold og rum - at virke både motiverende og engagerende på de adspurgte.

Flertallet af de interviewede børn synes dog også at være enige om vigtigheden $\mathrm{i}$ at blive behandlet med respekt, blive talt til på en rar måde, og at den enkelte træner udviser engagement og entusiasme i læringsprocessen. Dette illustreres tydeligt i to børns oplevelser fra et badmintontilbud i SSB i DGI-byen. S (dreng på 12 år) og J (pige på 12 år) går nu begge til badminton på Frederiksberg (se foto 3), men gik tidligere til badminton i DGI-byen. Årsagen til at de stoppede deres badminton træning i DGI-byen begrundes af J med, at der hele tiden blev taget nye deltagere ind på holdet. Herved blev oplevelsen af idrætstilbuddet utilfredsstillende, fordi hun følte, at hun blev overset af træneren og ikke fik den vejledning, hun havde brug for til at udvikle sig spillemæssigt. 
"... der var ikke rigtig nogen grænse for, hvor mange vi kunne være på holdet, til sidst var vi 31 og der var tre-fire lærere, hvoraf de to kunne spille badminton, så det virkede lidt rodet, som om det bare var sådan et fritidshjem eller et eller andet, hvor man bare løb rundt og spillede lidt badminton"

J følte sig tydeligvis overset og dårligt behandlet:

( , pige på 12 år, ØS, familieinterview, 11-02-2010)

"... der blev ikke rigtig taget hånd om os, der havde gået et år, vi blev bare sat ned i bagenden og spille"

J's mor understreger det ved at sige:

(J , pige på 12 år, ØS, familieinterview, 11-02-2010)

"Og netop dem, der kunne noget, fik ikke nogen udfordring, I blev bare sat ned i et hjørne og spille, det var det, J var rigtig glad for det, men ville gerne blive bedre, men der var ikke rigtig nogen progression i det"

(J's mor, ØS, familieinterview, 11-02-2010)

På Frederiksberg udtrykker hun derimod, at hun bliver hørt, set og behandlet ligeværdigt: blank linje indsættes

"Vores træner er 15 år så han er meget på alder med os, så han behandler os som ligemænd"

( , pige på 12 år, ØS, familieinterview, 11-02-2010)

Det betyder tilsyneladende mere for hende at blive behandlet ligeværdigt og at blive respekteret end at deltage, hvilket nedenstående tydeligt indikerer:

"Betyder det, du får lov at bestemme mere?"

blank linj e indsættes

(interviewer)

"J a altså, vi kan godt selv komme med et program, hvis vi vil lave et program, hvis vi vil, så vil han prøve at se, om der er noget, vi kan lave fra det"

"Har I så gj ort det?"

(J , pige på 12 år, ØS, familieinterview, 11-02-2010)

"Nej, for jeg synes, det er fint nok"

(interviewer)

(J , pige på 12 år, ØS, familieinterview, 11-02-2010)

Pigen giver udtryk for frustration over ikke reelt at blive set og hørt. For dem er respekt og anerkendelse afgørende for, om de holder ved et idrætstilbud, som de har meldt sig til - og måske også for deres aktive deltagelse. Til spørgsmålet om, hvorvidt de ville vende tilbage til DGI-byen, hvis tilbuddet kunne leve op til deres forventninger om at blive behandlet som 'ligemænd', er svaret:

"Ja"

(J , pige på12 år, ØS, familieinterview, 11-02-2010)

"Det var rigtig ærgerligt, at vi skulle skifte det var perfekt dernede og hun kunne selv gå frem og tilbage så det jo meget mere bøvlet, så det da klart det fedeste, hvis det var i DGI-byen"

(Mor til J , pige på12 år, ØS, familieinterview, 11-02-2010) 
Det ser ud til, at gensidig respekt er vigtigere end muligheden for medbestemmelse for børnene i de organiserede idrætsaktiviteter. Ser man på kritikken af de enkelte tilbud, drejer den sig mest om den pædagogiske formidling med afgørende betydning for børnenes motivation og engagement.

Generelt har børn et ønske om at blive behandlet med respekt, set og hørt af en træner, der udviser engagement og entusiasme. Dette bekræftes af andre udtalelser fra et fokusgruppeinterview med børn fra anden, fjerde, sjette og ottende klasse. I nedenstående citat spørges børn om, hvordan de synes, at en voksen skal være for at bidrage til børnenes motivation og engagement:

"Meget som det vi snakkede om, at man godt selv kan være med til at bestemme noget, han finder meget på de samme ting, og det er vildt kedeligt, kedelige lege, og så presser han os helt vildt meget"

(E, pige, 4. kl. ØS, fokusgruppeinterview, 27-01-2010)

"Det skal nok være en, som presser én lidt ud i det, så man kan lære det, men også én der vil være der, hvis man slår sig eller sådan noget"

(J, pige, 6. kl., ØS, fokusgruppeinterview, 27-01-2010)

"De skal ikke være for strenge eller for hårde, man skal synes, det er sjovt, ellers gider man ikke"

(B, dreng, 8. kl., ØS, fokusgruppeinterview, 27-01-2010)

"Sød, sige det på en sød måde, så man ikke bliver sådan krøllet sammen indeni én"

(K, pige, 2. klasse, ØS, fokusgruppeinterview, 27-01-2010)

Børnene i dette fokusgruppeinterview giver også udtryk for, at det er vigtigt for dem at være involveret i beslutninger og vigtigt ikke at blive presset for meget. Tilrettelæggelse, organisering og udformning af aktiviteterne i de respektive organiserede idrætsformer ser altså ud til at have stor betydning for børnenes engagement og oplevelse af at trives i og med deres idrætsaktiviteter. Det er fx vigtigt at blive støttet til en god start, særligt når man starter midt i en sæson. Flere af børnene oplever, at de bliver presset i den organiserede idræt på en måde, som de finder ubehagelig og stressende. Børnene har gode oplevelser, når deres træner presser dem på en passende og afbalanceret måde, så de lærer spillet og udvikler sig undervejs, men de understreger, at det er vigtigt, at det foregår på en måde, som gør det til en god oplevelse. Som J udtrykker det, så skal en træner være engageret i at ville lære hende noget:

"J eg synes, han skal være, som om han virkelig har lyst til at lære én det - vores træner er kun 15 år godt nok, men han snakker hele tiden med os og behandler os som ligemænd og sådan - han taler ikke ned til os og det virker, som om han har lyst til at lære os det - retter lidt på os, men ikke sådan voldsomt meget" 


\section{Foto 3}

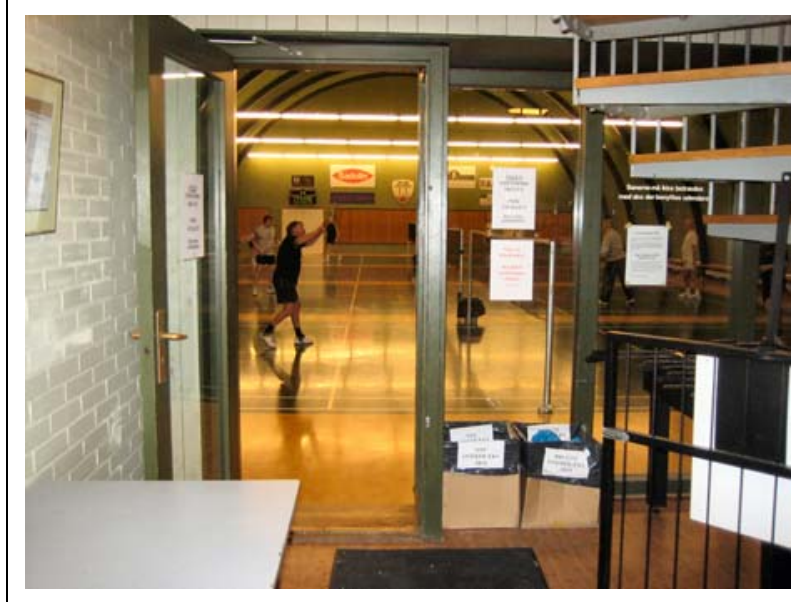

Badmintonklub på Frederiksberg i en

tilsvarende traditionel sportshal som i DGI-

byen.

(Foto: J, pige på 12 år, $\varnothing \mathrm{S}$, familieinterview)

Sammenfattende kan man sige, at samspillet mellem foreningernes organiserede idrætsaktiviteters form og struktur, de organiserede rums traditionelle form og rummenes kulturelle medbetydninger har positiv betydning for de adspurgte børns motivation og engagement i deres idrætsaktiviteter.

Foto 3 er fra Frederiksberg Badmintonklub. Idrætshallen er traditionel og tilsvarende DGI-byens sportshal, men formen på træningen er ifølge børnene mærkbart anderledes, hvilket betyder at de bliver motiverede og engagerede i idrætstilbuddet. Den faktor, der ser ud til at have størst indflydelse på børns motivation, er altså at blive respektfuldt behandlet og uden for meget pres at blive understøttet i en udvikling i forhold til idrætsaktiviteten. Ydermere ønsker børn en slags indflydelse på aktiviteternes udformning inden for den organiserede struktur, for at tilbuddet ikke bliver for ensformigt og kedeligt.

\section{Rum, spil og sikkerhed}

Dette afsnit belyser børns og familiers opfattelse af deres muligheder for selv-organiseret spil (fodbold, badminton osv.) i organiserede rum og dets betydning for børns motivation og engagement i forhold til fysisk aktivitet i dagligdagen. Det drejer sig derfor om at afdække børns og familiers opfattelse af udbuddet af rum på Vesterbro, hvor de kan igangsætte egne fysiske aktiviteter dvs. selv-organiseret spil i organiserede rum. Der ses desuden på, hvilke rum der begrænser, og hvilke der fremmer fysisk aktivitet ud fra rummenes funktionalitet og sikkerhed.

Flertallet af de adspurgte børn organiserer selv fysiske aktiviteter i hverdagen på steder, hvor der er større eller mindre grad af faciliteter til de former for spil, som de gerne vil dyrke. De bruger boldbanerne på Vesterbro, særligt 'de røde baner' og 'Skydebanen', 'skaterbanen', 'bure', mindre 'grønne spots' eller små pladser eller åbne rum i bydelen - og i mindre grad 
parker og skolegårde. Enghaveparken er den park, som børnene kender bedst og bruger mest. De beskriver også, hvordan de ofte bruger både Valbyparken og Søndermarken uden for bydelen dog mest til selv-organiseret leg. Byens gårdmiljøer spiller en særlig stor rolle i forhold til selvorganiserede fysiske aktiviteter i selvorganiserede rum, hvilket vil blive belyst i næste afsnit.

Det tiltaler børnene, at steder og rum er beregnede og velegnede til spil af forskellig slags. De bruger ofte organiserede rum, der har banefaciliteter som 'de røde baner', 'Skydebanen', 'Sønder Boulevard' og 'bure' eller baner ved deres fritidshjem og klubber. Disse steder byder på gode muligheder for boldspil. Rummene giver desuden mulighed for, at de kan organisere spil spontant sammen med deres venner, fx venner som de ikke går til foreningsidræt sammen med. Ydermere giver disse rum mulighed for 'at der kan støde nye til', dvs. de er åbne for, at de kan lade andre komme ind i spillet og dermed lære nye børn at kende. Børnene bruger dog også de rum i bydelen, som ikke har faciliteter til boldspil, fx mål og kurve; her konstruerer de selv de fornødne faciliteter.

Flere af de nævnte steder ser ud til at være genstand for en vis utryghed og bekymring blandt børn og deres familier. En mor oplever, at der er steder, hvor hun og hendes børn kommer $\mathrm{i}$ hverdagen, der opleves utrygge pga. områdets misbrugsmiljø. Hun mener ikke, at hendes børn kan færdes alene i lokalmiljøet, hverken i deres egen gård, i parker eller på nærliggende legepladser pga. den manglende oplevelse af sikkerhed.

Flere af børnene oplever utryghed, enten når de går til og fra steder, hvor de leger frit, eller på selve stedet, de bruger og foretrækker til spil og leg. Deres utryghed relateres særligt til bydelens misbrugsmiljø, men også til unge, der færdes i grupper og opleves som 'bander', der agerer truende ol. Børnene har som oftest ikke selv oplevet noget ubehageligt, men de har hørt om det, og denne utryghed synes at fylde en del i deres hverdag.

"Hvis jeg er alene, så går jeg hurtigt, så kigger jeg mig bag ryggen"

(M, pige, 6. klasse, TV, fokusgruppeinterview, 20-01-2010)

"Det gør jeg også, der er så mange, der bliver voldtaget"

( $P$, pige, 6. klasse, TV, fokusgruppeinterview, 13-01-2010)

"Ja, det gælder nok mest for piger"

(D, dreng, 8. klasse, TV, fokusgruppeinterview, 13-01-2010) 
Citaterne ovenfor indikerer desuden - og ikke overraskende, at denne utryghedsfølelse er mere udbredt blandt piger end blandt drenge.

I det følgende præsenteres de steder og rum på Vesterbro, som de interviewede børn har fremhævet som omdrej ningspunkt for deres fysiske aktiviteter i hverdagen.

\title{
Skydebanehaven
}

Et sted, der i særlig grad fremhæves, er Skydebanehaven, der ligger på det centrale Vesterbro. Skydebanehaven er en bemandet legeplads om dagen, som iflg. både børn og deres forældre ændrer karakter om aftenen. To børn beskriver uafhængigt af hinanden, hvorledes de finder det svært at overskue Skydebanehavens ændrede miljø om aftenen.

\begin{abstract}
"Der har jeg været et par gange med mine veninder, hvor at der har været skummelt, og der har stået nogle bander på den måde og snakket lidt sammen, og der har jeg ikke helt kunne gennemskue, hvad de lavede, ikke for at lege detektiv, for min egen sikkerheds skyld" (Al, pige på 11 år, VNS, familieinterview, 04-02-2010)

"Næh altså, når det er mørkt, så jeg ikke så meget for at gå igennem, fordi jeg synes tit, der er nogle drenge eller noget, der gemmer sig i buskene, dem som er derinde og sammen der, jeg er ikke så vild med at gå igennem der"

(S, dreng på 12 år, ØS, familieinterview, 11-02-2010)
\end{abstract}

Også de voksne ser ud til at opleve utryghed omkring Skydebanehaven om aftenen. En mor bekræfter denne opfattelse af utryghed uden personligt at have oplevet en konkret hændelse.

"Der er ret skummelt på Skydebanen, når det bliver mørkt, jeg har det selv sådan, når jeg går igennem dernede, så det bare ud på trods af, jeg har boet her i 20 år, så har jeg det stadig sådan, at jeg godt kan gå og kigge mig over skulderen"

(Mor til M, pige på 12 år, TDS, familieinterview, 04-02-2010)

To af de i alt 24 adspurgte børn og familiemedlemmer kan beskrive konkrete, personlige oplevelser, hvor de har følt sig truet eller direkte har været udsat for overgreb.

En storebror til en af de interviewede piger på 11 år fortæller om en oplevelse, hvor han på vej hjem til Humleby gennem Skydebanehaven blev overfaldet af nogle drenge, han ikke kendte.

"J eg har egentligt ikke tænkt over det før, men her for nogen dage siden oplevede jeg nogle drenge, der var lidt ubehagelige og kastede sne på mig, og gav mig vaskere, og lagde mig ned, som jeg egentlig ikke kendte, så det var en lidt chokerende oplevelse"

(Storebror, 15 år, til Al, pige på 11 år, VNS, familieinterview, 04-02-2010) 
Det ser ud til, at familier generelt er utrygge ved Skydebanehaven og området omkring på en sådan måde, at det begrænser børnenes frie bevægelse - enten fordi de selv fravælger at bruge området, eller fordi forældrene beder dem lade være. Fælles for de interviewede børn og forældre er, at de nævner den manglende belysning som en stor del af årsagen til deres utryghed, idet gadebelysningen tilsyneladende minimeres om aftenen.

"... basket kan jeg godt spille, men jeg går aldrig ud, hvis det er mørkt, man skal tænke sig om, for man ved jo aldrig, hvad der kan ske"

(Af, pige 5. kl., VNS, fokusgruppeinterview, 13-01-2010)

\section{Enghaveparken og Enghave Plads}

Enghaveparken og Enghave Plads er to andre steder, hvor både børn og voksne føler sig utrygge og derfor ikke kommer særligt ofte. En pige siger, at det er pga. for mange berusede mennesker. En anden siger, at hun føler sig forulempet pga. ubehagelige tilråb og en tredje, at det er pga. rygter om 'bandeaktivitet".

En mor og to børn giver udtryk for, at de ikke blot finder Enghaveparken og Enghave Plads for utryg pga. misbrugsmiljøet, men også pga. oplevelser med drillerier og trusler fra bandelignende grupper af unge drenge - eller rygter om samme. Nedenstående citat bekræfter, at der er en stor forskel på, hvordan lokalmiljøet bliver opfattet i dagtimerne og når mørket falder på i bydelens park.

"Nogen gange Enghaveparken, i Enghaveparken er der mange fulde mennesker, og det er derfor, jeg ikke går der så meget"

(Mor til An, pige på 11 år, ES, familieinterview, 30-01-2010)

"Ovre i Enghaveparken var jeg sammen med nogle veninder, og så kom der sådan nogle store piger og gjorde nar af os og alt muligt, og så blev vi sådan lidt bange, og så truede de os, da vi sagde, at de skulle stoppe... de sagde, at vi var grimme og alt muligt"

(E, pige 4. kl., VNS, fokusgruppeinterview, 13-01-2010)

Men Enghaveparken kan godt være farlig om aftenen, fordi der er en slags store drenge, som siger, de er gangstere og går rundt og truer børn, der går i 6 . kl. eller 0.-6. kl., de går meget her på Vesterbro ved Enghave"

(Y, dreng 5. kl., VNS, fokusgruppeinterview, 13-01-2010)

Det er - tilsvarende Skydebanehaven - tilsyneladende kun om aftenen, at miljøet i og omkring Enghaveparken opfattes som utrygt af børnene. Denne utryghed afholder dem - på samme måde som ved Skydebanehaven - fra at komme på Enghave Plads, selvom der er et boldbur, som mange af børnene finder attraktivt og ville være glade for at kunne bruge (se foto 4 og 5 nedenfor). 

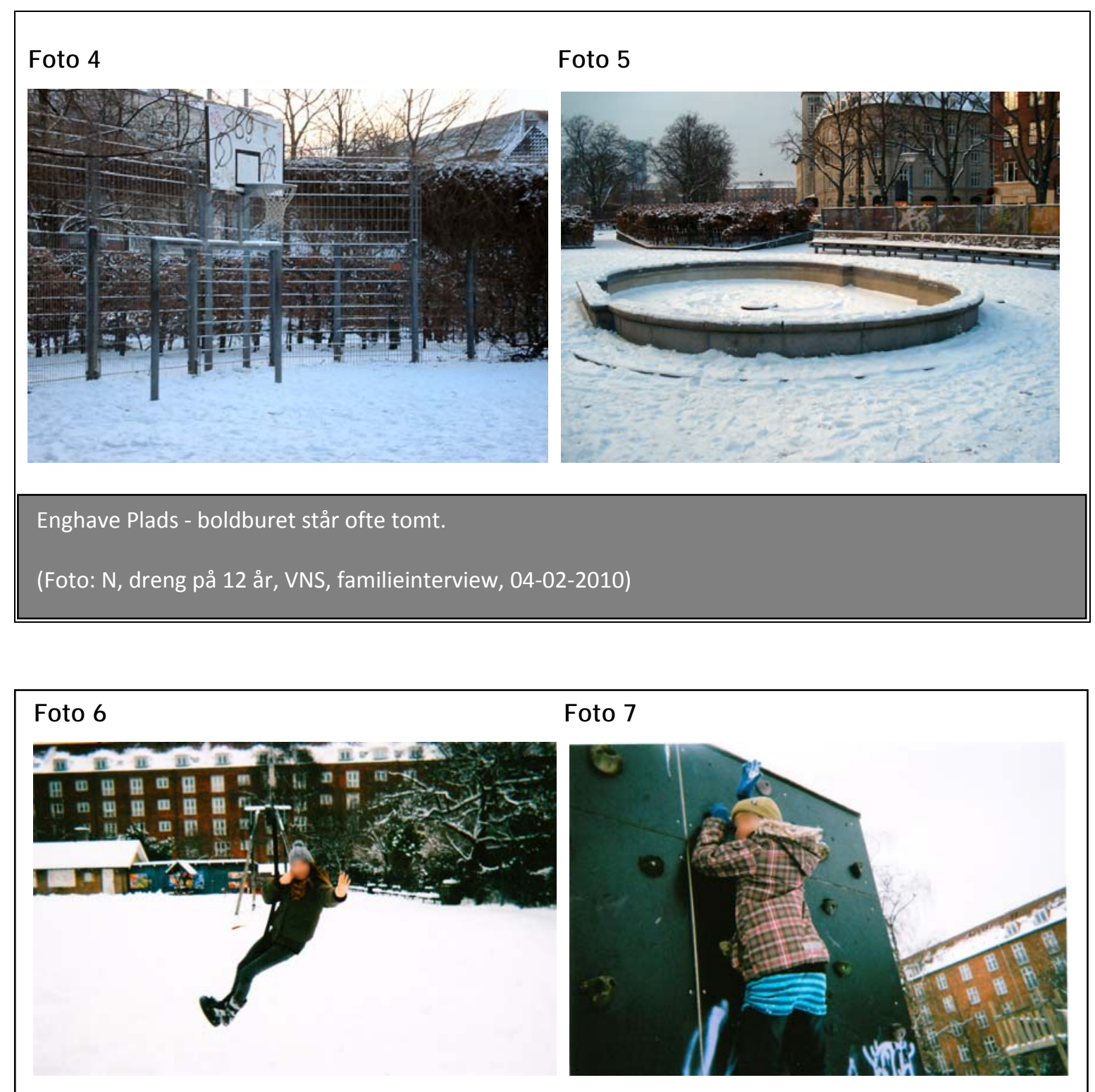

Klatrevæg og svævebane som M flittigt bruger sammen med veninderne.

(Foto: M, pige på 12år, TDS, familieinterview, 04-02-2010)

Ifølge børns og forældres udtalelser er der knapt så utrygt i Enghaveparken. Foto 6 og 7 ovenfor bekræfter og illustrerer netop dette. Om dagen er der livlig aktivitet. Børn leger og bevæger sig trygt omkring i området.

\section{De røde baner}

De røde baner er ligeledes et af de steder, hvor nogle børn har haft ubehagelige oplevelser. De røde baner er tre baner, hvor børn frit kan spille fodbold eller basket. Om sommeren bliver der opsat to idrætscontainere med forskellige legeredskaber. Til de to containere er der tilknyttet to pædagoger, ligesom i tilsvarende ordninger med bemandede legepladser andre steder i Køben- 
havn. Rummene her indikerer samme funktion og kultur som DGI-byens sportshal, men ifølge børnenes udsagn foregår der andet end boldspil her. Børnene beretter om unge drenge, der driller og virker farlige. Dette forekommer både om dagen og om aftenen. I et fokusgruppeinterview fortæller en dreng, at han føler sig utryg ved at komme på de røde baner, fordi der er mange store drenge, der gerne vil slås.

"J a, hvis man ikke føler sig godt tilpas, eller som A sagde, bliver bange, nogle gange kommer der drenge, som siger, de vil smadre én, hvis man ikke flytter sig på banen, så vil de smadre én, sådan nogle drenge kan jeg ikke lide"

\section{(Y, dreng 5. kl., VNS, fokusgruppeinterview, 13-01-2010)}

\section{Foto 8}

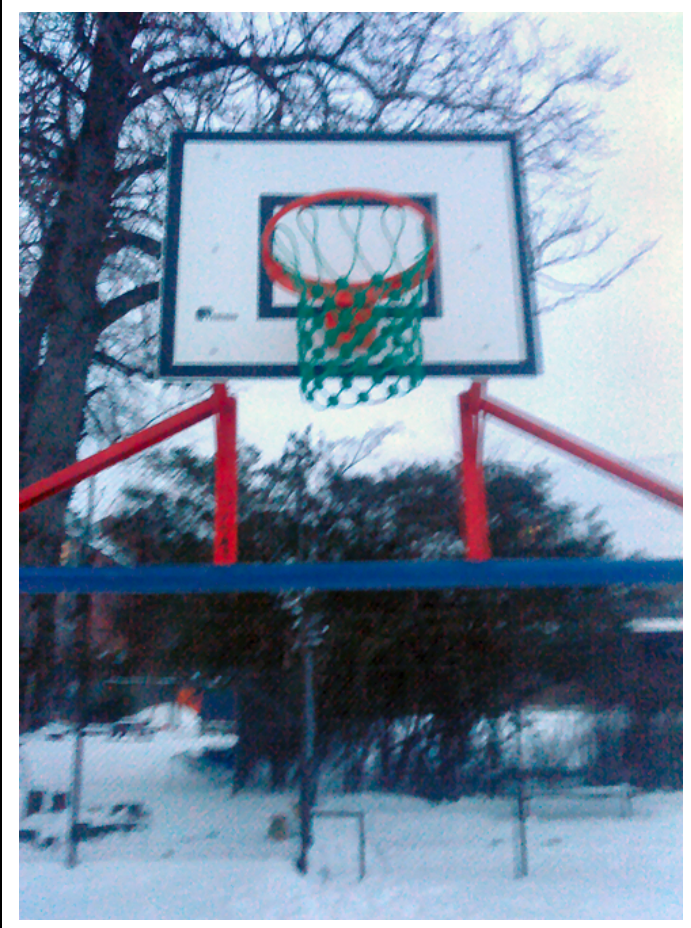

\section{Foto 9}

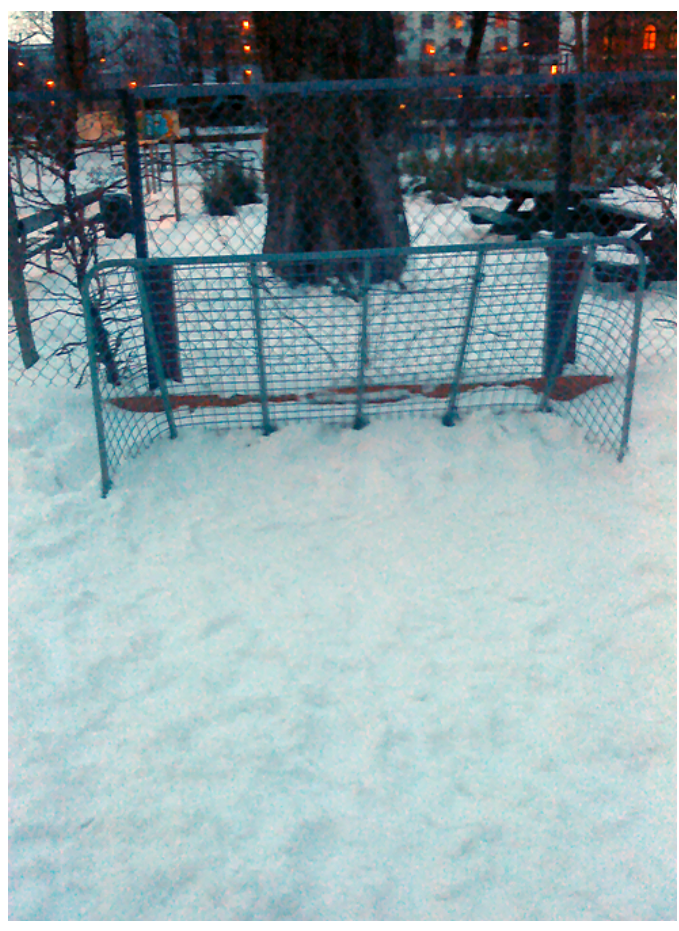

De røde baner, hvor S spiller bold med vennerne efter skoletid.

(Foto: S, dreng på 12 år, familieinterview, 11-02-2010) 
En anden pige giver udtryk for frygt, der udspringer fra konkrete oplevelser ved de røde baner:

"Der er nogle gange nogle drenge som kommer og truer én en gang imellem, det er der ... de truer bare og så er der, de der AK81 ... så blev vi bange, man skal jo være bange for dem for tænk, hvis de gør noget"

(Af, pige 5. kl., VNS, fokusgruppeinterview, 13-01-2010)

"... spiller de også, eller kommer de bare for at lave ballade?"

(interviewer)

"Nej, de kommer for at spille, og så truer de børnene med, at de skal gå ud og det, så de kan komme ud og spille"

(Af, pige 5. kl., VNS, fokusgruppeinterview, 13-01-2010)

Ovenstående citat viser også, at der nogle steder er en konflikt mellem større og mindre børn. Nogle af de mindre børn føler sig 'presset ud af boldbanen' og må opgive den fysiske aktivitet. At frygt og utryghed vælger børnene at blive hjemme i stedet for at dyrke aktiviteter udenfor, viser citatet nedenfor:

"Så på en måde ødelægger det børnenes lyst til at være kreative på en måde ..., så tænker de nok, jeg ... kommer ikke igen, eller jeg bliver hj emme, jeg tager ikke chancen"

(Y, dreng 5. kl., VNS, fokusgruppeinterview, 13-01-2010)

Interviewene viser samtidig, at ikke alle unge er lige uvenlige. Børnene taler også om ældre og mere venligtsindede drenge. Men de føler ikke, de kan søge støtte hos disse drenge. Dette gælder også for de voksne, der er tilknyttet stedet. Efter deres opfattelse har de uvenlige børn ikke respekt, hverken for de voksne eller de venligtsindede drenge og udgør derfor en fare - også for voksne:

"Så man holder sig nogen gange væk, fordi man faktisk er bange for dem?"

"Ja"

(interviewer)

"J a"

(Y, dreng 5. kI., VNS, fokusgruppeinterview, 13-01-2010)

(Af, pige 5. kl., VNS, fokusgruppeinterview, 13-01-2010)

"Men der er også nogle andre store drenge, som er flinke nok, jeg har nogle venner, som er store fra 8. klasse og sådan"

(Y, dreng 5. kl., VNS, fokusgruppeinterview, 13-01-2010)

"Kan I sige det til nogle voksne, at der kommer nogen på den røde bane som?" (interviewer)

"Det ser også ... det kan være farligt, hvis man siger det til de voksne, så kan de komme op at skændes, fordi de ser rigtig urespektløse ud"

(Af, pige 5. kl., VNS, fokusgruppeinterview, 13-01-2010) 
Ikke alle børn oplever denne frygt. Fx omtaler en af de interviewede piger banerne meget positivt, og hun bruger stedet sammen med sine veninder efter skoletid. I fotoregistreringen viser hun de røde baner, hvor hun hænger ud med veninderne (se foto 10 nedenfor).

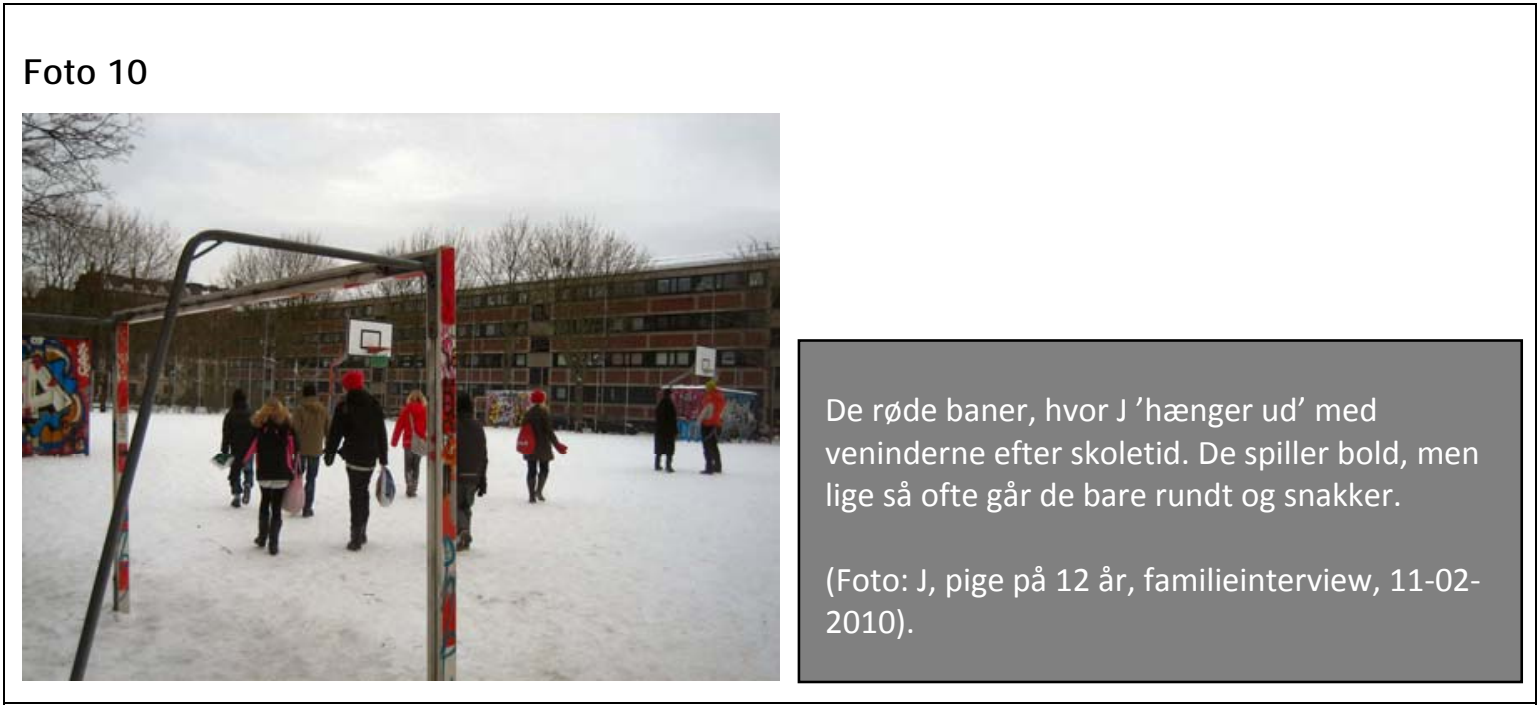

\section{Sønder Boulevard}

Et andet sted, der af flere børn opleves som utrygt, er Sønder Boulevard. Nogle få andre børn beskriver dog dette område som et spændende sted, hvor der er sjovt at komme, fordi man bliver taget godt imod af andre. Disse børn beskriver den sociale kultur som særlig tolerant og imødekommende og føler sig derfor velkomne og godt tilpas. Det er dog kun meget få af de udspurgte børn, der anvender området. Ingen af de børn, der deltog i fotoregistreringen, har taget billeder af området. Årsagen til dette skyldes delvis utryghed i forhold til områdets miljø, delvis fordi området ikke opleves som værende attraktivt.

Interviewene viser generelt, at børn og forældre holder sig på afstand af og er påpasselige med at komme i dette område. En mor henstiller til datter om ikke komme på Sønder Boulevard, fordi hun er bange for prostitutionsmiljøet i området, og fordi hun synes, det er for langt væk fra, hvor de bor.

"J eg tror jeg er bare sådan skruet sammen, at jeg har det bedst, hvis hun er lige i nærområdet og jeg synes, selv om de har renoveret Sønder Boulevard, så synes jeg stadig, den virker sådan lidt skummel, og det levn fra tidligere tider med hele det ry som Sønder Boulevard og Halmtorvet har haft, så j eg bryder mig ikke specielt meget om det, altså det kan godt være jeg havde haft det anderledes, hvis det var en dreng, men nu er det en pige, det er ikke så langt fra Halmtorvet, Skelbækgade og alt det her"

(Mor til M, pige på 12 år, TDS, familieinterview, 04-02-2010)

Hvortil datteren tilføjer:

"Ikke så langt fra de der mennesker, der voldtager"

(M, pige på 12 år, TDS, familieinterview, 04-02-2010) 
Til interviewers spørgsmål om dette skyldes både prostitutionsmiljøet og narkomiljøet, siger M's mor:

"Også narko, men dernede er der ikke så meget narko, det er mest prostitutionsmiljøet altså det er jo desværre, Skelbækgade jo altid haft ry for, at det er dernede, de purunge piger starter, ... og så har jeg det sådan, at hvis man færdes på Sønder Boulevard, så bliver man et nemt offer, jeg har selv prøvet at blive antastet tre gange"

(Mor til M, pige på 12 år, TDS, familieinterview, 04-02-2010)

Hvorefter datteren på ny tilføjer:

"Men jeg tror også, vi er også meget tæt knyttet til hinanden, mig og min mor, fordi det kun er hver anden weekend, jeg er hos min far, men jeg tror også, det er lige så meget, fordi vi har sådan et tæt bånd, at hun er så utryg ved, at jeg er så langt væk hjemmefra"

(M, pige på 12 år, TDS, familieinterview, 04-02-2010)

Dette citat vidner om, at der også kan være personlige og familiemæssige årsager til børns og forældres utryghed - og ikke udelukkende faktorer relateret til de enkelte rum og steder i bydelen. Ydermere indikerer forældres udtalelser, at der er en kønsmæssig forskel i forhold til, hvor familien mener, at henholdsvis piger og drenge bør og må færdes. Denne forskel får igen betydning for børns færden og medvirker til at afholde nogle helt væk fra bestemte områder på Vesterbro.

En dreng beskriver en tur hjem fra fodboldtræning gennem Istedgade en vinteraften efter kl. 18, hvor han oplever nogle unge mennesker blive anholdt af politiet:

"Der var sådan 5 - 6 personer, der blev tilbageholdt af noget politi, og så var der så noget, så var der kastet med nogle flaske, det var sådan lidt uhyggeligt at gå der, man vidste ikke rigtigt, hvad man skulle gøre af sig selv, gå frem eller tilbage"

( $N$, dreng på 12 år, familieinterview, 04-02-2010)

På interviewers spørgsmål om hvad han så gj orde, siger han:

"J eg gik bare videre .... og så da jeg kom forbi, så løb jeg et lille bitte stykke"

( $N$, dreng på 12 år, familieinterview, 04-02-2010)

Denne dreng udviser den samme utryghed som moren ovenfor, men hans reaktion er en anden; han afholder sig ikke fra at komme i området. Hans oplevelse kunne ellers godt have resulteret i samme reaktion, som hos mange af de andre interviewede børn og forældre; at vælge en anden rute hjem fra aktiviteterne. Men trods sin utryghed formår han at anvende den samme rute igen. Der er altså overordnet forskel på, hvordan børn og deres forældre opfatter risikoen forbundet med at bevæge sig på Vesterbro og hvordan de handler i forhold til den.

For nogle af de interviewede børn og deres familier ligger der personlige og konkrete oplevelser til grund for deres utryghed og frygt, i andre tilfælde bygger den på rygter og 'vandrehistorier'. Nedenstående citat vidner om dette: 
"En gang var jeg og mine venner i biografen, så blev mine venner bange, fordi at lige omme bag Carlsberg fritidshj em, der siger de, de står, og hvis man kommer i nærheden, så halalslagter de én"

(Al, pige på 11 år, VNS, familieinterview, 04-02-2010)

"O.k., hvad betyder det?"

(interviewer)

"Det betyder, at det sådan rimeligt pressende"

(Al, pige på 11 år, VNS, familieinterview, 04-02-2010)

"Hvem er det, unge fyre - bander?"

(interviewer)

"Det ved jeg ikke, jeg har aldrig set dem"

(Al, pige på 11, VNS, familieinterview, 04-02-2010)

Undersøgelsen viser, at følelse af tryghed kan basere sig på personlige og konkrete oplevelser, men lige så ofte i 'andenhåndsberetninger' fra bekendte, der også kan 'vandre', eller socialt konstruerede ry, der ofte kan relateres til steders fortidige miljø.

De forskellige interviews vidner også om, at utryghed håndteres forskelligt. Hvor nogle af de interviewede vælger at undgå visse steder, vælger andre at tackle deres utryghed med humor. For eksempel vælger en pige og hendes familie en humoristisk tilgang for herved at bevare troen på, at der ikke sker noget ubehageligt og uhyggeligt. Til interviewers spørgsmål, om hvorvidt J's lillebror til tider føler sig utryg på Vesterbro, svarer han og familien:

"Ja"

"Hvorhenne?"

(J's lillebror)

"J eg tror, det var hernede et sted"

(interviewer)

(J's lillebror)

"Altså, vi har Café 42 her nedenunder, hvor der er rigtig mange alkoholikere, inde ved siden af er en ting, vi ikke ved, hvad det er, men som vi tror, er en hashklub, som man godt kan blive utryg

(J, pige på 12, ØS, familieinterview, 11-02-2010)

"Hvad er det, man udsætter sine børn for?" (Mor griner let) (Mor til J): "Så der kan man godt blive lidt utrygt nogen gange ved, at der står en bænk, hvor der er tisset op og en skraldespand og fulde mænd, der kommer ud af Cafe 42 og siger 'hej smukke'"

(J , pige på 12, ØS, familieinterview, 11-02-2010)

"Men det lyder, som om du bare kan grine af det?"

"Ja"

(interviewer)

"De gør aldrig nogen fortræd"

( , pige på 12, ØS, familieinterview, 11-02-2010)

(J's lillebror) 
Pigen (J) fra citatet ovenfor foretrak at 'hænge ud' med veninderne følgende steder: De Røde Baner, Vesterbro Torv, Otto Krabbes Plads (foto 11 og 12). Disse pladser betragtes ligeledes af de fleste som utrygge steder, men hun og veninderne kommer her alligevel. De gynger lidt på gyngen på Vesterbro Torv, og de sidder på murene på Otto Krabbes plads og snakker "pigeting" uden ubehagelige oplevelser forårsaget af Vesterbros misbrugsmiljø.

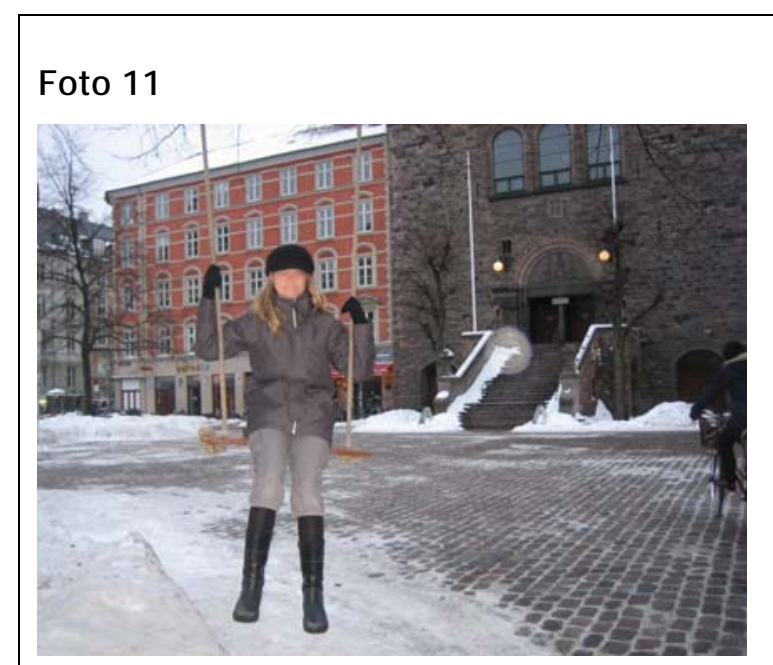

Foto 13

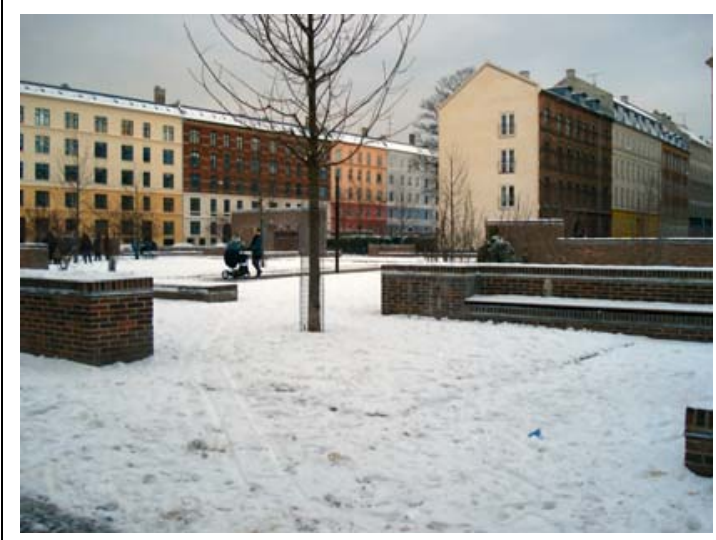

\section{Foto 12}

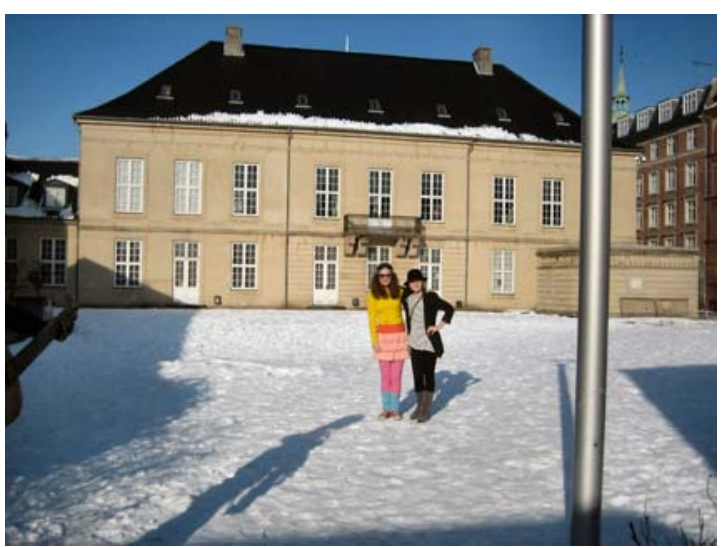

Foto 14

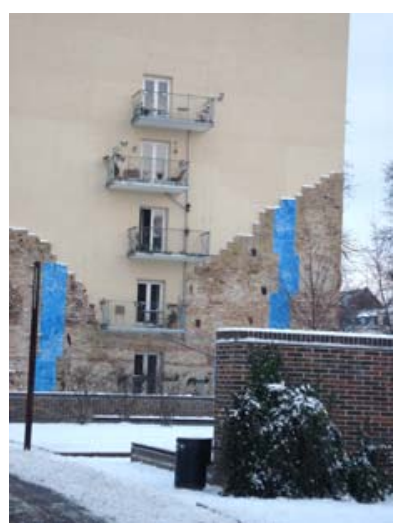

Fotos af 'hænge ud-steder' med veninder: Vesterbro Torv og Otto Krabbes Plads.

(Foto: J, pige på 12 år, ØS, familieinterview, 11-02-2010)

Børns og familiers ubehag eller frygt for frygt eller ubehag ved at bevæge sig på bestemte steder på Vesterbro ser altså ud til at få afgørende indflydelse på valg af sted og rum for deres selvorganiserede aktiviteter. Det tyder på, at graden af rums organisering, deres faciliteter og deres indirekte omgangskvalitet $f x$ indikation af, at der her er plads og rum for børns og unges spil og leg, har en meget lille betydning, hvis stederne føles utrygge pga. deres miljø. Spørgsmålet om sikkerhed er derfor essentielt for børns og deres familiers fysiske aktivitet og bevægelsesfrihed $\mathrm{i}$ hverdagen. 
Når man spørger børn, hvad der skal til, for at de vil føle sig trygge, efterlyser de voksnes tilstedeværelse i højere grad og henviser i den sammenhæng til en generel følelse af større tryghed i skolen. Enkelte børn giver dog udtryk for en misbilligelse ved voksnes tilstedeværelse, da de opfatter den som en slags kontrol og potentiel barriere for deres medbestemmelse $\mathrm{i}$ relation til deres selv-organiserede aktiviteter. En pige giver i et fokusgruppeinterview udtryk for en bekymring for, at voksnes tilstedeværelse også vil betyde en indskrænkning af hendes mulighed for medbestemmelse. Umiddelbart kunne det tolkes, som om hun foretrækker en vis autonomi og medbestemmelse frem for trygheden ved voksnes tilstedeværelse - men interviewet viser også, at denne pige ikke selv har haft ubehagelige oplevelser omkring de steder, hun foretrækker til spil og leg.

"J eg har ikke været ude for sådan noget, jeg har prøvet ikke at syntes det var fedt, at der er hele tiden er nogen, som holder øje med én, det er jo ikke fedt"

(Al, pige, 5. kl., VNS, fokusgruppeinterview, 13-01-2010)

"J o, for hernede er det jo godt, hvis der er en voksen, for hvis der er nogle store, som siger til de små; ' 'kan I så fucke ud' og så hvis de små bliver bange, og så ikke kan gøre noget, og hvis der så er en voksen, så kan den voksne så måske gøre noget"

(Af, pige, 5. kl., VNS, fokusgruppeinterview, 13-01-2010)

"Det er selvfølgelig rigtigt, jeg tror bare, jeg vil have det sådan, at der er en voksen, og så hvis man bare gør noget forkert, så kommer de hele tiden og retter på én"

(Al, pige, 5. kl., VNS, fokusgruppeinterview, 13-01-2010)

"Så det skulle være nogle voksne, som kunne passe på én, men ikke ville blande sig så meget?"

"Ja"

(interviewer)

"J a"

(Af, pige, 5. kl., VNS, fokusgruppeinterview, 10-01-2010)

(Y, dreng, 5. kl., VNS, fokusgruppeinterview, 10-01-2010)

"Et overvågningskamera! De blander sig ikke!"

(Al, pige, 5. kl., VNS, fokusgruppeinterview, 10-01-2010)

"Bare en voksen som gik rundt og som så, om der sker noget"

(Y, dreng, 5. kl., VNS, fokusgruppeinterview, 10-01-2010)

Generelt synes denne omfattende utryghed hos mange både børn og deres familier dog ikke at fratage dem lysten til at bo på Vesterbro. Deres utryghed ved særlige områder på Vesterbro hæmmer måske nok deres muligheder for selv-organiseret fysisk bevægelse, men det afholder dem ikke helt fra steder, hvor de kan udfolde sig. Børn og deres familier giver - på trods af denne utryghed - udtryk for, at de oplever, at der er gode betingelser for både idrætsudøvelse i foreninger og for at bruge bydelens steder til selv-organiseret spil i dagtimerne. 


\section{Rum, leg og regler - kreativitet}

Dette afsnit belyser børns og familiers opfattelse af deres muligheder for selv-organiseret leg $\mathrm{i}$ selv-organiserede rum og dets betydning for deres motivation og engagement.

Et af de rum på Vesterbro, som stort set alle nævner som et sted, de kommer - på trods af utryghed - er Skydebanen. Skydebanen er en legeplads, beliggende på det centrale Vesterbro. Efter renoveringen af Skydebanen er det nogle af børnenes opfattelse, at den ikke længere henvender sig til børn på deres egen alder, men i stedet til de yngste børn. Med udgangspunkt i børnenes beskrivelser kan man sige, at legepladsen er blevet for organiseret til en bestemt målgruppes brug. Det er fx ikke længere muligt at køre på cykel rundt på legepladsen. De større børn mener, at der er for mange fysiske forhindringer, og at de voksne griber ind i deres lege af hensyn til de små børn og for at 'håndhæve' stedets nuværende organisering og kulturelle medbetydning.

"Nu synes jeg, før den blev bygget om, så synes jeg også godt, man kunne bruge den sammen med vennerne og bruge den til måske at cykle rundt og lave noget sjovt dernede, men efter den er bygget om, så synes jeg den, så er den bare blevet lidt mere for små børn"

(S, dreng, 12 år, ØS, familieinterview, 11-02-2010)

\section{Foto 15}

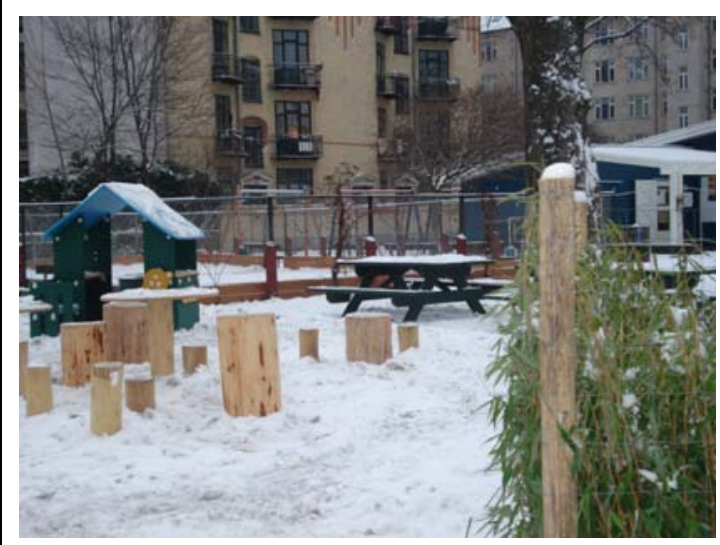

\section{Foto 16}

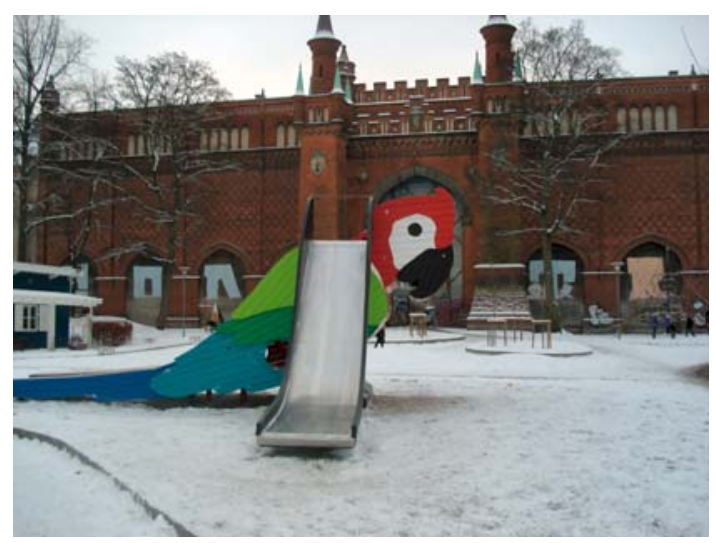

J og S er utilfredse med, at Skydebanen er blevet renoveret. De synes ikke, at den nye udformning henvender sig til dem og deres aldersgruppe, men kun til yngre børn. Før kunne de cykle og spille bold, men nu kan man hverken det ene eller det andet pga. høje og nye legeredskaber såsom små legehuse og træstubbe (se foto 15). Særligt papegøjen (se foto 16) er de utilfredse med, fordi den står og spærrer for en tidligere selv-organiseret cykelbane.

(Foto: J og S, фS, familieinterview, 20-01-2010)

På trods af deres utilfredshed med renoveringen fortæller en del af de interviewede børn, at de fortsat jævnligt kommer der for at bruge både klatrenet og svævebane (se foto $17 \mathrm{og} 18$ ). Man 
kan sige, at de indtager rummet på ny og på trods. De finder på nye lege, hvortil rummets nye funktion kan bidrage.

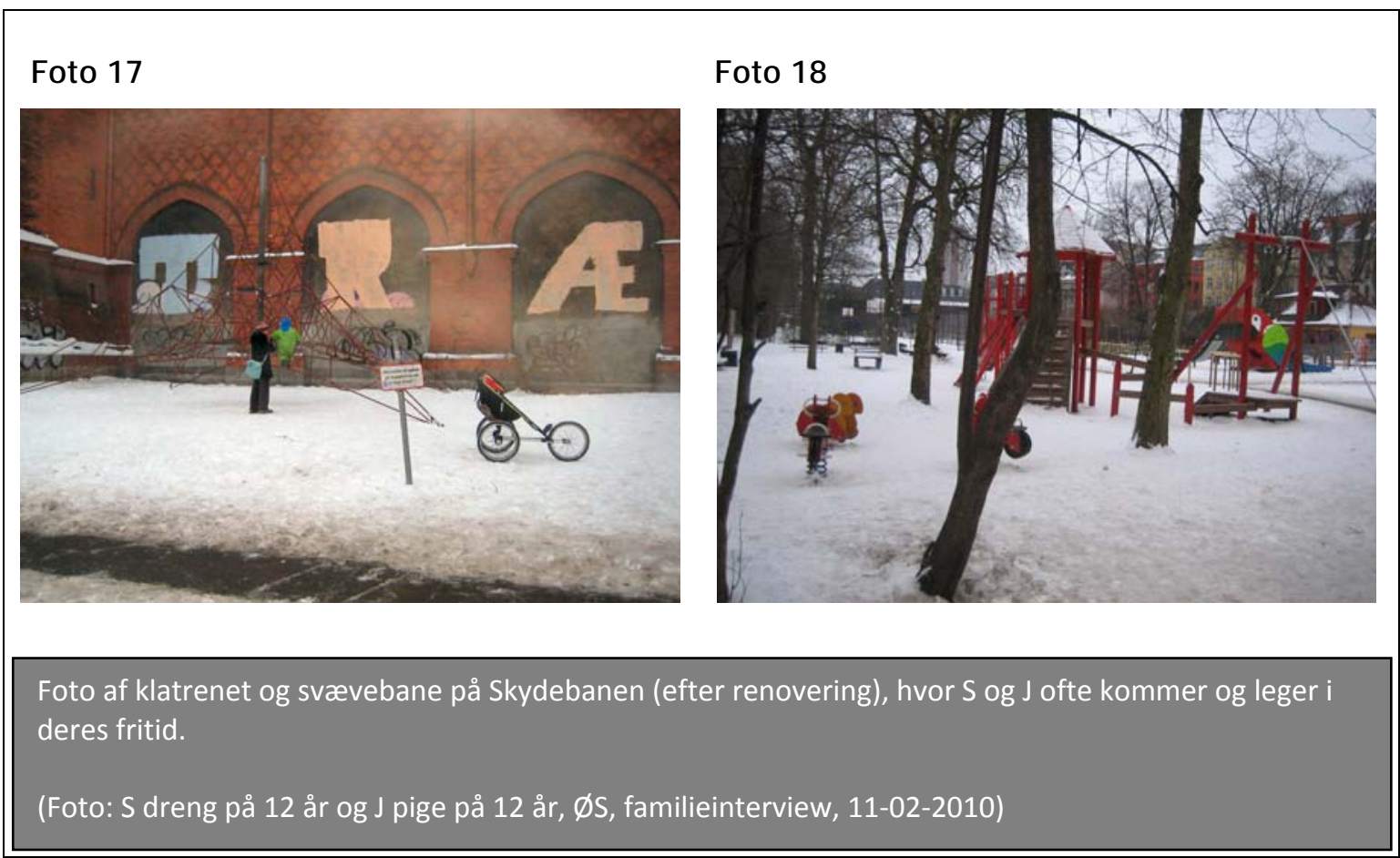

Skydebanens meget organiserede fysiske rum synes ikke blot at give god mulighed for forskellige selv-organiserede fysiske aktiviteter, men til dels også at begrænse børn i mere kreative lege og udfoldelser. Rummenes direkte omgangskvaliteter begrænser altså som helhed børns fysiske aktivitet. Rummenes mere indirekte kvaliteter i form af kulturelt bestemte regler og voksnes indblanding begrænser yderligere børnenes udfoldelser og aktivitet.

Når man spørger børn, om de synes, det er nemt at finde steder, hvor man kan lege på Vesterbro uden voksenindblanding, svarer en dreng:

"Mellemting - der er nogen steder hvor man bare ikke kan være, uden der kommer en eller anden og ligesom ...for det meste, ikke for at være onde mod gamle mennesker, men det er ret tit gamle mennesker, der syntes vi larmer for meget"

(N, dreng på 12 år, VNS, familieinterview, 04-02-2010)

På trods af rummenes til tider meget organiserede design og kulturelle medbetydninger, dvs. normer og fastlagte regler, så formår børnene alligevel på kreativ vis at omdanne rum til deres 
ønskede fysiske aktiviteter. Ved blot at lave små ændringer af rummene med medbragte objekter, tilpasser de rummet til deres lege.

Børns medbragte ting er altså med til at ændre både rum og leg. Nedenstående citat vidner om dette. Pigen fortæller, at hun indimellem tager kridt med ud for at optegne gårdens rum, således at rummets funktionelle rammer bliver omskabt til at opfylde legens behov. En dreng tager en papkasse med til at spille fodbold med, hvorved legen får en anden betydning for ham og hans ven. Disse to børn beskriver, hvordan de ændrer rummet til at imødekomme deres behov, hvorved rummets funktionalitet brydes og et nyt skabes.

"... der er også et sted, hvor der bare er asfalt, hvor der sådan er helt plant, sådan helt firkantet, så der kan man bare, hvis man har nogle papkasser eller et eller andet, så tog S. i hvert fald engang, en fra min klasse, en papkasse med og så spillede vi bare fodbold på den ... det er sådan lidt sydafrikansk, vi syntes det var lidt Ronaldino-agtigt"

(N, dreng på 12 år, VNS, familieinterview, 04-02-2010)

"J a, vi bruger kridt"

(P, pige 5. kl., ES, fokusgruppeinterview, 11-01-2010)

"Så I arrangerer og gør med gården, så I kan gøre, hvad I har lyst til?"

(interviewer)

"J a, så bruger vi kridt og tøj til at lave helle"

(P, pige 5. kl., ES, fokusgruppeinterview, 11-01-2010)

Et optimalt samspil mellem et aktuelt rum og den legeaktivitet, der vælges eller ønskes, ser ud til at være vigtigt for børnene. Hvis samspillet ikke fungerer efter hensigten, så omdanner de selv rummene og tilpasser dem deres leg. Børn er altså på denne måde handlekompetente medskabere af bydelens rum.

\section{Potentialer}

Dette afsnit belyser børns og familiers opfattelse af rum, der ifølge dem i særlig grad fremmer deres fysiske aktivitet, og som derfor også har særlig betydning for deres motivation og engagement. Det belyses gennem børns og familiers iagttagelser og beskrivelser af 'det gode rum' for fysisk aktivitet.

\section{Gårdes og parkers potentialer}

Gårdene og parkerne har ifølge børnenes udtalelser helt særlige rumlige potentialer, der kan understøtte og fremme kreative og frie børnelege. Vesterbros gårde bliver flittigt brugt af børnene til leg og spil med venner og familie. Har de ikke selv adgang til et appellerende gårdmiljø, har 
de ofte en ven, en kusine eller fætter, som har adgang til et gårdmiljø, hvor de kan spille og skabe lege.

Gårdene synes desuden også at frembyde en god mulighed for selv-organiseret leg og spil for især gruppen af piger med anden etnisk oprindelse end dansk. Det er piger, der giver udtryk for at have begrænset tid til at gå ud selv eller til foreningsidræt pga. pligter. Gårdene beskrives som værende meget harmoniske; fri for konflikter og følelsen af utryghed. Gårdene er ofte store og har mange tilbud i form af varierede faciliteter. En typisk - om end meget stor - gård på Vesterbro beskrives som nedenfor:

"Det er en kæmpestor gård, det er faktisk en af Vesterbros største gårde, den strækker sig her fra Matthæusgade og hele vejen ned til Istedgade, et af de første grønne gård-projekter, den har sådan lidt nogle kanter med boldbure og sandkasser til de små, lidt bede og grillområde"

(Mor til N, dreng på 12 år, VNS, familieinterview, 04-02-2010)

Børnene fortæller at de i gårdene leger mange traditionelle lege såsom fangeleg, gemmeleg og dåseskjul, men også nyere lege eller lege, som de selv skaber i situationen fx ved at omforme regler fra kendte lege.

"Er det dåseskjul og gemmeleg og sådan?"

"J a, der er ret mange gemmesteder"

(interviewer)

"J a, blod på væggen ... det er et nyt spil!"

(K, pige 2. kl., ØS, fokusgruppeinterview, 27-01-2010)

(R, dreng, 2. kl., ØS, fokusgruppeinterview, 27-01-2010)

Alle børn er tilsyneladende gode til selv at sætte aktiviteter i gang, og de bruger særligt gårdene til dette. Oplevelsen af at kende de andre børn og voksne, der kommer i gården, opfattes af flere som trygt og rart. 
"J eg går ikke rigtig til noget, om søndagen går jeg på koranskolen, men ellers hvis der er nogen i gården, går j eg ud til dem, men ikke noget fast, da jeg går til koranskole"

$$
\text { (T, pige, 5. kl., ES, fokusgruppeinterview, 11-01-2010) }
$$

"Er det nogen, I kender godt?"

"J a, de bor i vores gård, en kæmpe gård, og der er mange muslimer, der er ikke så mange danskere, så vi er der nede i gården, og vi kender dem rigtig godt"

(T, pige, 5. kl., ES, fokusgruppeinterview, 11-01-2010)

"... der er mest tyrkere, de er meget ude og sidder på bænke og drikker te og kaffe, det er hyggeligt, det er meget godt"

(An, pige, 5. kl., ES, fokusgruppeinterview, 11-01-2010)

Gården, som de to piger refererer til, hører til en privat bebyggelse og er en af Vesterbros største gårde. Gården er åben, går fra Vesterbrogade ned til Matthæusgade og fungerer som genvej for mange mennesker på Vesterbro. På trods af at den er frit tilgængelig for gennemgang, føler pigen An sig mere tryg her end på fx Skydebanen, fordi hun kender de fleste, som kommer her.

De to fotos nedenfor (foto 19 og 20) viser gården, som er en gennemorganiseret gård med traditionelle faciliteter. Her er boldbure til de store og klatredrage til de små. An har valgt at tage billeder af disse to steder, fordi hun kommer her med sin lillebror, der leger på dragen, mens hun selv bruger boldburet.

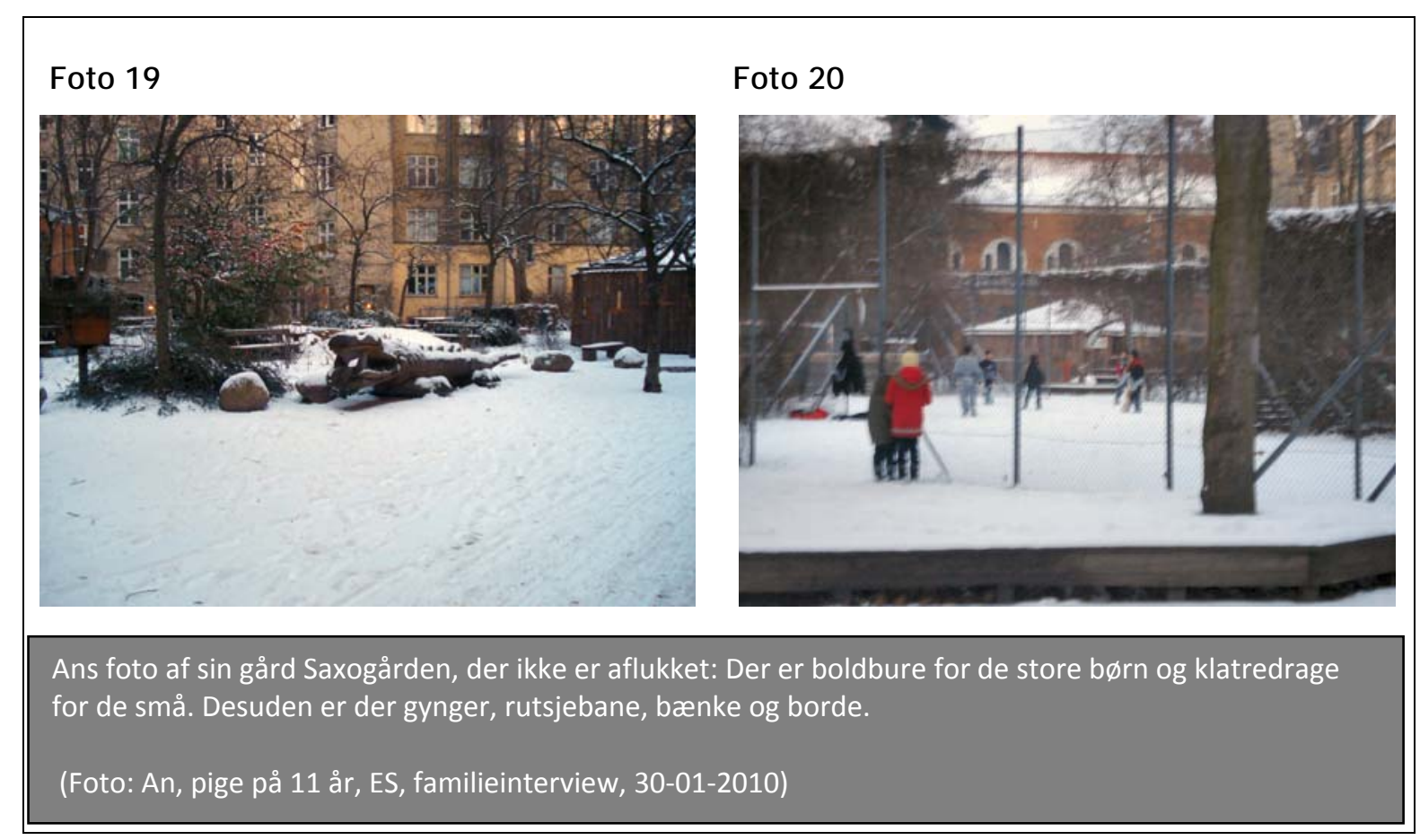


En anden dreng har den samme oplevelse af gården som en tryghedsskabende faktor, i og med den er aflukket, og han kender alle de andre børn og voksne (se foto 21 og 22 nedenfor). S beskriver sin gård som specielt attraktiv om sommeren, når der stilles en trampolin op til fælles brug for alle børnene i gården.

"J eg bruger min gård - jeg kender mange i gården, så mødes man der, når det er varmere og hygger sig, vi har en stor trampolin, som vi kan tage ud og så er vi der sammen"

(S, dreng på 12 år, 6. kl., ØS, fokusgruppeinterview, 27-01-2010)

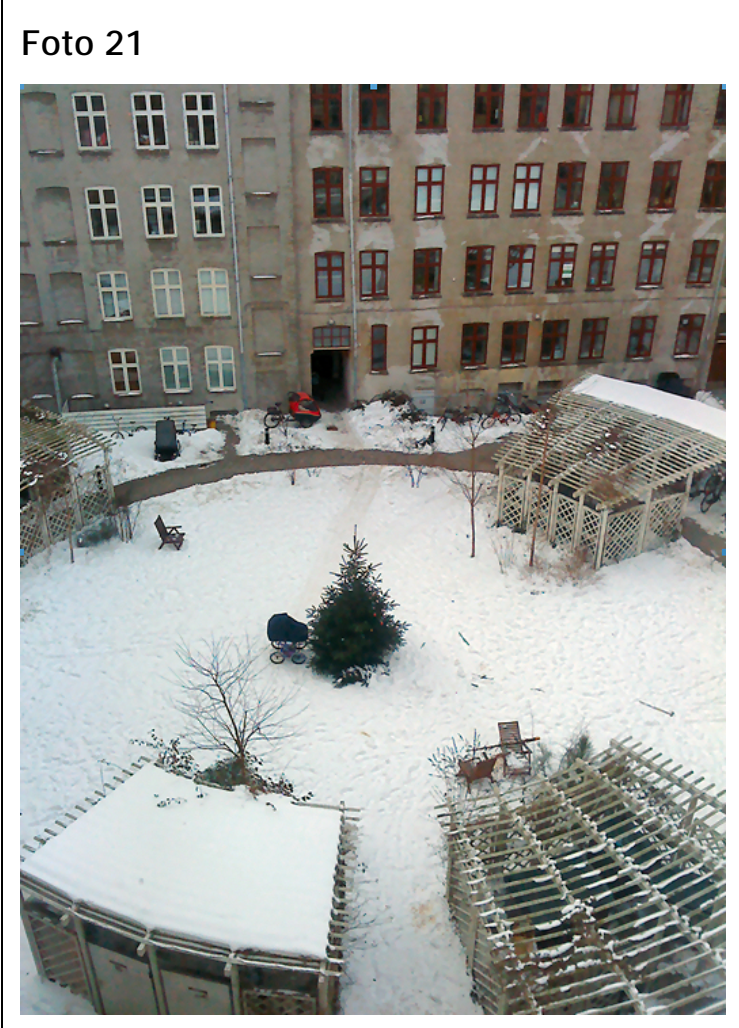

Foto 22

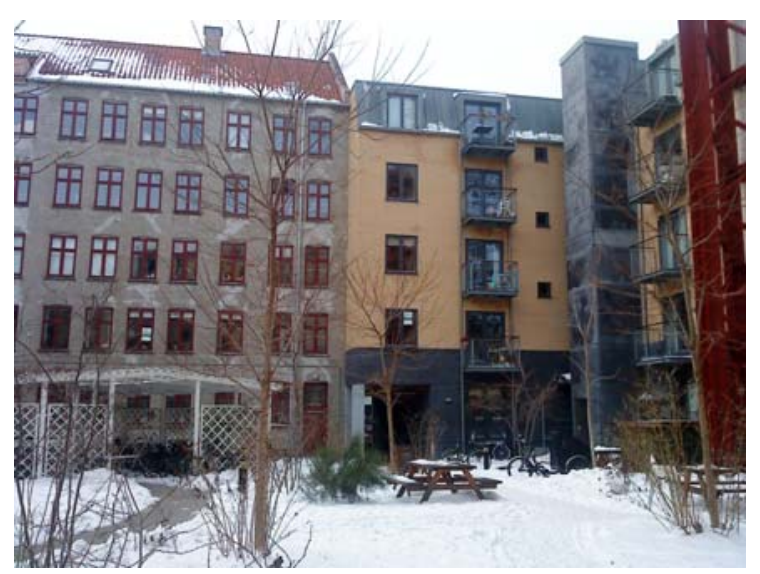

S's foto af egen gård, hvor der om sommeren stilles en stor trampolin op, som alle beboere og gæster kan bruge. Gården indeholder desuden bænke, borde og skure.

(Fotos: S, dreng på 12 år, ØS, familieinterview, 11-02-2010)

Når børnene spørges om, hvorvidt de synes, der er mange gode steder for leg på Vesterbro, nævner de særligt bydelens gårde og parker. En dreng fremhæver en stor gård i en bebyggelse $\mathrm{i}$ Viktoriagade som det særligt 'gode sted'. Det er tilsyneladende størrelsen og ikke trygheden i gårdens lukkede rum, der er afgørende, når han skal lege gemme- og fangelege: 
"Hvis I tænker på, hvor I bor på Vesterbro, er der mange gode steder til at lave sine egne lege?"

(interviewer)

"Njah, måske nogle gange ... hos min fætter i Viktoriagade ... fordi han har sådan et rigtig stor gård og der kan man finde på rigtig mange gode lege ... kender du gemmefange?"

(R, dreng, 2. kl., ØS, fokusgruppeinterview, 27-01-2010)

En af de interviewede piger oplever ikke sin gård som optimal ramme for hendes egne og veninders lege, hvilket medfører, at hun og veninden ændrer på rummet og dets funktion - ligesom det før blev beskrevet, at andre børn gør - for herved at skabe de ideelle rammer. Hun opfatter sig selv som god til at skabe rum og legeaktivitet i sin gård og fortæller, at hun sammen med sine veninder har lavet en kælkebakke (se foto 23 ).

"... ellers synes jeg også at min gård, den er ikke sådan lige total legepladsagtigt vel, men det er sådan, at man selv kan arrangere noget dernede, især når der er sne, der har vi lavet en kæmpe kælkebane og alt muligt"

(M, pige på 12 år, TV, familieinterview, 04-02-2010)

"Vi brugte et bord så hele vejen ned, det kan man faktisk også se på billederne, at der står et helt bord, der var sådan et træ, lige når man kommer ned, det skal man lige skal passe på, man ikke kommer ind i, så skal man lige bremse med foden"

(M, pige på 12 år, TV, familieinterview, 04-02-2010)

Pigernes kreative ændring af rum og rammer vidner om en stærk vilje, motivation og handlekompetence, der ikke lader sig hæmme af ydre vilkår, men i stedet får omsat ideer til virkelighed. Selvom det 'gode legerum' ifølge denne pige ikke på forhånd eksisterer i hendes gård, så bliver gårdens rum alligevel til et godt rum for leg via de forandringer, hun selv skaber. Rums 'modstand' ser til tider ud til at 'trigge' til en kreativ proces, hvor samspil mellem rum og leg bliver justeret ${ }^{3}$ (J ustiniano, 2009).

\footnotetext{
${ }^{3}$ Dette bekræftes af en undersøgelse gennemført i forbindelse med et ph.d.-projekt, hvis resultater beskrives i ph.d.afhandlingen: "Somaæstetisk blik på undervisningsiscenesættelse - et epistemologisk og didaktik eksperiment".
} 


\section{Foto 23}

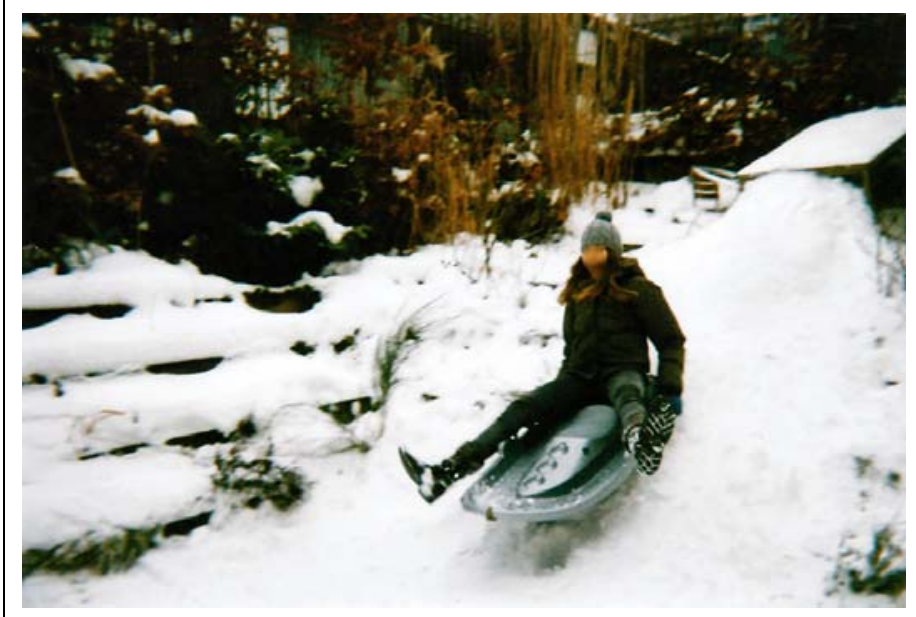

$\mathrm{M}$ har taget billedet af sin

hjemmelavede kælkebakke i sin private gård

(Foto: M, pige på 12 år, TV,

familiegruppeinterview, 04-02-2010)

En anden pige fortæller, at hun ønsker sig uberørte naturområder, såsom Søndermarkens mindre organiserede form, til rum for sine udfoldelser. For hende er det særligt 'gode legerum' der, hvor man kan naturklatre, og rummet er naturligt formet:

"Der skal være træer, Søndermarken fx, så kan man lave alle mulige mærkelige ting" (prøver at vise det)

(Al, pige, 11 år, 5. kl., VNS, fokusgruppeinterview, 20-01-2010)

"Man kan klatre i træer, lave konkurrencer, der er bakker, jeg kan godt lide, at det hele er naturligt, og så kan man bare være mærkelig"

(Al, pige, 11 år, 5. kl., VNS, fokusgruppeinterview, 20-01-2010)

Søndermarken nævnes af flere andre børn som et godt sted for leg, fordi dets mindre organiserede og funktionskodede form giver mulighed for anderledes frie lege. Et godt legerum er tilsyneladende et ikke-organiseret rum, som kan indtages på dets egne præmisser. Ud over at børn beskriver Søndermarken som en god ramme for leg, så fremhæves den ligeledes som en meget velegnet ramme for familiehygge. Flere af børnene og familierne anvender både Søndermarken og Valbyparken som udflugtsmål om sommeren til leg og hygge:

"Søndermarken og Valbyparken der er godt, der er jeg om sommeren sammen med familien, om aftenen eller i weekenden, det er rigtig sjovt, når det er godt vej r, vi spiser og leger og ser på det der vand, hvor der er haletudser og leger i det, vi leger på legepladsen, rutsj ebanen er sjov"

(Af, pige 5. kl., VNS, fokusgruppeinterview, 04-02-2010) 
Nogle gange kan et i forvejen eksisterende objekt i givne omgivelser give en speciel mening for børn, fx et særligt træ. Til hverdag anvender Al, en af de interviewede piger, Enghaveparken til leg og hun nævner i den forbindelse et særligt træ, hvor hun og veninderne gerne afholder skovtur i trætoppen om sommeren (se foto 24). Enghaveparkens knap så frie legerum beskrives som en " $0 . k^{\prime}$-erstatning for Søndermarkens helt frie rammer.

\section{Foto 24}

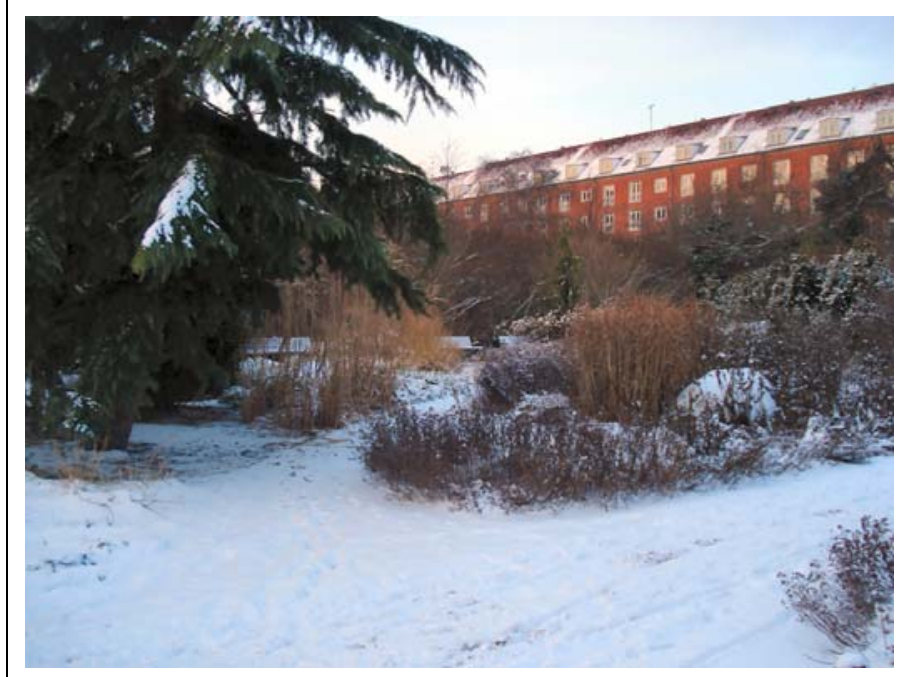

Træet i Enghaveparken hvor Al og

hendes veninder tager på skovtur om sommeren.

(Foto: Al, pige på 11 år,

familieinterview, 04-02-2010)

I det følgende citat fortæller Al, at dette træ giver hende og hendes veninde mulighed for venindesnak i fred for andre mennesker. Her kan hun være mærkelig, uden at der er nogen, der ænser det.

"Nå nej, det er Enghaveparken, der er sådan et rigtig sjovt træ, der klatrer man sådan op i det og så kan man sidde oven på trækronen, det er meget hyggeligt"

"Min veninde og jeg, vi havde et tæppe og satte os op i sådan et træ, og vi havde æggemadder og hytteret med og juice og alt muligt"

"Vi sidder og snakker, og så nogen gange laver vi nogle mærkelige ting"

(Al, pige, 11 år, VNS, familieinterview, 04-02-2010)

Denne pige lader sig inspirere af rummets kreative muligheder og forstår til fulde at anvende dem. Det er tydeligvis rummets uformede rammer, der taler til hende og optimerer hendes leg.

Parkers og gårdes mindre kodede rum og talrige krinkelkroge ser ud til at tilbyde børn rum og rammer, der åbner for valg og brug af rummene. Det medvirker til at skabe mere kreative og nuancerede lege som fx Als og venindens skovtur i parkens trætop. Gårdene er store og tilbyder 
mange varierende faciliteter. Det ser således ud til, at gårdanlægs og parkers mindre organiserede rum giver børn en oplevelse af større frihed og tryghed, når de vil spille og lege. Gårdene ser ud til at have stor betydning for børns bevægelsesfrihed, idet de ofte er afgrænsede og aflukkede. Det giver deres forældre tryghed, at børnene ikke kan løbe ud.

Meget organiserede rum, fx Skydebanen, ser derimod ud til at begrænse denne aldersgruppe af børn i deres kreative selv-organiserede aktiviteter. Alligevel afholder Sønder Boulevards nu mere gennemorganiserede rum ikke børn fra selv at forsøge at bryde med dette områdes meget organiserede rum. Kulturelt konstruerede rum og deres indlejrede kulturelle medbetydning ser ud til at få indflydelse på børns fysiske bevægelsesmuligheder pga. regler og voksenindblanding. Der synes netop for mange af børnene at være en stor tilfredshed i selv at kunne bestemme over sin legeaktivitet uden voksenindblanding. Citatet nedenfor illustrerer dette:

"... i vores gård der er det sådan; hvem vil være med til politi og røvere, og hvem vil være med til pigerne efter drengene og sådan, fangeleg, hvem vil være med, og så kommer de, og så leger vi"

(T, pige, 5. kl., ES, fokusgruppeinterview, 11-01-2010)

"Så styrer I det hele selv uden voksne?"

"Ja"

(interviewer)

(T, pige, 5. kl., ES, fokusgruppeinterview, 11-01-2010)

Der synes at være et udbredt ønske blandt børnene om fysiske områder, der er knap så organiserede, og hvor man selv kan indtage rummene og præge dem, så de passer til den ønskede leg. Men ikke bare børnene har et stort ønske om 'frie rum', de selv kan præge. Også forældre udtrykker ønsker om dette. En mor udtrykker sin frustration over manglende frirum, idet alle de offentlige rum, som hun har adgang til i nærmiljøet, er blevet så gennemorganiserede og fulde af regler, at enhver fri udfoldelse er blevet besværliggjort. 
"Vi kan godt mærke, når vi laver sådan nogle sociale arrangementer med klassen og de fx foreslår; nu skal vi spille en rundboldkamp, det kan ikke lade sig gøre. Og så efter de har ændret oppe i Frederiksberg Have, så har de jo lavet sådan nogle nye regler om i Frederiksbergs Have, at man skal ansøge, hvis man er flere end 25 mennesker, så skal man ansøge om at gøre noget, og så bliver det lige pludseligt meget besværligt, hvis man skal lave klassearrangement hvor man skal spille rundbold"

(Mor til S, dreng på 12 år, ØS, familieinterview, 11-02-2010)

"Så skal man helt op i Søndermarken?"

(interviewer)

"I Søndermarken må man heller ikke, du må ikke, vi har på et tidspunkt i S's klasse forsøgt at lave et sommerarrangement, hvor vi skulle lave forskellige ting; spille rundbold, og der var nogle, der skulle spille tennis og vi satte et stangtennis ned, så kom der simpelthen nogle parkbetjente, der sagde, vi skulle hive det op og hvis vi ikke gjorde det nu, så fik vi bøder og ... altså det der med at gøre sådan nogle ting det har vi ikke ... til det der med klasser og store grupper, så gør vi så noget andet, så bowler vi DGI-byen, og mødes og drikker kaffe på Skydebanen bagefter og sådan nogle ting ... vi har ikke den der store park med den store græsplæne, hvor man kan mødes og spille fodbold"

(Mor til S, dreng på 12 år, ØS, familieinterview, 11-02-2010)

\section{Rummet og spillet der tillader kreativ leg og deltagelse}

Nogle rum og aktiviteter ser ud til at skabe særligt gode betingelser for kreative leg og deltagelse. Én af drengene (S) fortæller i et familieinterview, at han går til rollespil i Valbyparken. Denne dreng beskriver, hvorledes rummets og rollespillets dramaturgiske form giver ham særligt gode rammer for kreativ leg.

\section{Foto 25}

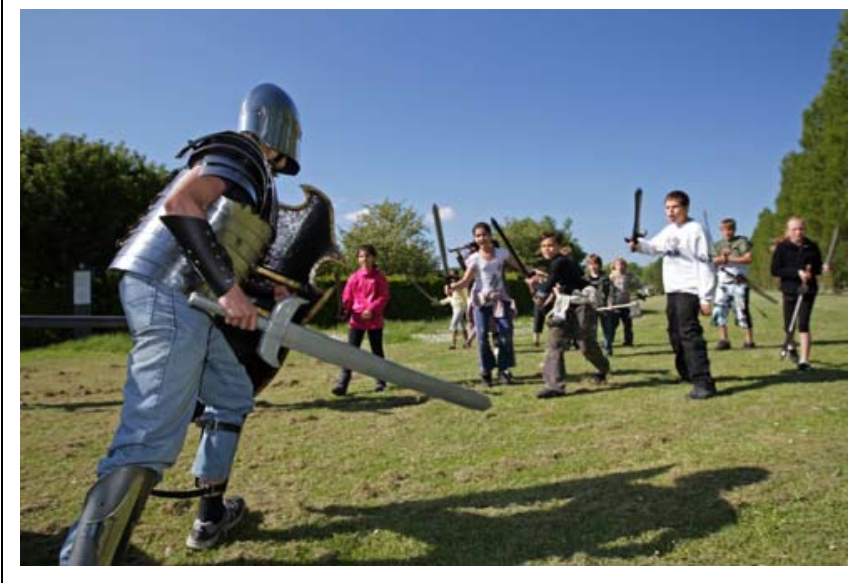

Billedet illustrerer en rollespilskamp i

Zone 2.

(Foto udlånt af Carsten Egevang, Zone 2 i Valby, hvor S går til rollespil)

Rollespillets dramaturgi giver ham mulighed for fri bevægelse uden hæmmende rum, regler eller voksenindblanding. $\mathrm{S}$ beskriver det således: 
"J o, altså, der løber vi meget rundt og kæmper, og jamen altså derude er der bare næsten ingen regler, så vi kan bare lave, hvad vi vil"

Og videre siger S:

"Valbyparken er bare så kæmpestor, og vi må løbe rundt på hele arealet"

(S, dreng på 12 år, ØS, familieinterview, 11-02-2010)

De voksne deltagere i rollespillet beskrives desuden som tilbageholdende i deres styring af spillets gang. De bestemmer og styrer spillets overordnede regler, men ikke spillets historik og gang. I spillets dramatiske udvikling lader de delvist børnene selv bestemme og styre forløbet, som S siger:

"... de fortæller ikke, hvad der sker"

(S, dreng på 12 år, ØS, familieinterview, 11-02-2010)

De voksne introducerer tilsyneladende kun med en lille forhistorie som en form for igangsætter af spillet, hvorefter børnene tager over.

Når voksne tillader, at børn bliver aktive medskabere af historiens gang, synes det at have stor betydning for deres engagement og deltagelse. Spillets processuelle historiske opbygning og muligheden for at præge denne tyder på, at fortællingen fungerer som en særlig form for drivkraft for børnene. Det samme synes at gøre sig gældende, når det drejer sig om regler for spillet og håndhævelsen af disse, hvilket nedenstående citater illustrerer: 
"J amen altså ikke rigtigt, men det kan godt være nogen gange, at de så siger, at de fortæller nogle historier, som hvad der er sket de sidste to uger, som de bare har fundet på med at fx der er en, der er død, og så vil nogle have hævn eller er meget sure, og så kan det være, de går i krig, men det bestemmer man selv"

(S, dreng på 12 år, ØS, familieinterview, 11-02-2010)

"Så de lægger op med en historie, som I bygger videre på?"

"Ja"

(interviewer)

(S, dreng på 12 år, ØS, familieinterview, 11-02-2010)

" ... altså der er nogle få regler med, at man ikke må slå for hårdt og være for voldelig"

(S, dreng på 12 år, ØS, familieinterview, 11-02-2010)

"Der er vel også nogen regler, hvor mange gange man bliver slået, hvor man er død, er der ikke det?"

(S's far)

"Jo, men så med hvis man har rustning på, så er der nogle flere liv, så er der også regler med, hvor mange liv man har, og hvornår man dør"

(S, dreng på 12 år, ØS, familieinterview, 11-02-2010)

Rollespillets meget begrænsede regelsæt synes ligeledes at motivere og engagere børn i spillet på en hel anden måde end andre former for spil og leg. Den pædagogiske form, som rollespillet tilbyder, ser altså ud til at give børnene en oplevelse af at være ægte deltager ${ }^{4}$ (Simovska, 2005 $\&$ 2007). Børn er med til i et fællesskab at skabe en historie, hvor alt kan ske. Processens uforudsigelighed og dynamik ser ud til at tilbyde noget helt specielt og meget anderledes end det, børn ellers kender til (J ustiniano, 2009) ${ }^{5}$.

"Hvad siger du til den form, er det en form du kender fra andre steder... skolen måske?" (interviewer)

"Nej, det synes jeg ikke overhoved ikke"

(S, dreng på 12 år, ØS, familieinterview, 11-02-2010)

"Så den form med du er aktiv deltagende, den kan du godt lide?"

(interviewer)

"J a, altså jeg synes, der mange steder er for mange regler særligt Skydebanen men også i klubben" (S, dreng på 12 år, ØS, familieinterview, 11-02-2010)

\footnotetext{
${ }^{4}$ Fgte deltagelse beskrives af Simovska som værende kendetegnet ved: 1) Et bredt fokus hvor børn selv er aktive i konstruktion af egen viden, 2) Åbne resultater dvs. de er ikke givne på forhånd, men skabes af børnene selv på baggrund af interesser, ideer og behov 3) Fokus på individerne i deres kontekst - hvor børn bliver støttet aktivt $\mathrm{i}$ at påvirke deres omgivelser og dermed tage ansvar for egen sundhed og liv (se desuden notat fra 2009: "State of the art notat", udarbej det af Simovska og Klyhs Albeck for DGI-byen).

${ }^{5}$ Dette bekræftes af J ustinianos ph.d. afhandling fra 2009, hvor en række konstruerede pædagogiske eksperimenter byggende på rollespillets struktur og form netop viser, at processens uforudsigelighed skaber en nysgerrighed og motivationskraft, der driver deltagerne videre i læreprocessen.
} 
S's beretning vidner om et behov for et sted, hvor børn kan være aktivt deltagende i legens udformning. Et sted, hvor de selv er reelle medskabere af den fysiske aktivitet, de deltager i, og hvor der ikke mindst er rum og rammer, der er vide nok til, at man selv kan forme eller omforme dem.

Nogle børn ser ud til at gå et skridt videre. De ønsker helt uberørte naturområder og fuldstændig autonomi, hvor der ikke er regler og helt uden voksen indblanding. De efterlyser teder med en uberørt fremtræden uden specifik funktion og som med deres umiddelbarhed giver børnene inspiration til deres leg.

En illustration af dette ses i citatet nedenfor. Al, en pige på 11 år, giver udtryk for, at hun mangler et sted, hvor hun kan naturklatre:

"J eg kan bedst li' sådan noget, hvor man klatrer på klipper og klatrer i træer sådan noget naturklatring, der er ikke noget klatrehold, der er sådan"

(Al, pige 11 år, VNS, familieinterview, 04-02-2010)

"J eg kan meget bedre lide at klatre i træer, der er faktisk nogle ude i Kongelunden, så er der sådan et væltet træ med en kæmpe rod, og så der også rigtig meget teknik"

(Al, pige 11 år, VNS, familieinterview, 04-02-2010)

"Kunne klatrevægge være et alternativ?"

"Nej, jeg vil hellere noget med naturklatring"

(interviewer)

(Al, pige 11 år, VNS, familieinterview, 04-02-2010)

Her er der altså ikke bare et ønske om mulighed for deltagelse, men om total autonomi til selv at styre, bestemme og konstruere rum og leg, men undersøgelsen giver som helhed indblik i, at børn generelt savner rum, der er knap så organiserede. Rum, som de selv kan præge, og pædagogiske rammer der giver mulighed for ægte deltagelse.

\section{Barrierer}

Dette afsnit belyser børns og familiers opfattelse af deres muligheder for fysisk aktivitet (idræt, spil og leg) ud fra et tidsmæssigt perspektiv, hvor arbejdsmæssige, skolemæssige og religiøse forpligtelser ser ud til at spille ind. Det drejer sig om at belyse, hvorledes de forskellige forpligtelser får betydning for børns og familiers hverdag.

\section{Arbejdsforpligtelser}

Familiers og børns tid - eller mangel på samme - ser ud til at være afgørende for deres fysiske aktivitetsniveau. Dette omhandler for forældrenes vedkommende deres tilsyneladende store arbej dspres og for børns vedkommende deres skolemæssige og religiøse pligter. 
De fleste interview vidner om familier med en travl hverdag, hvor man kommer sent hjem og ikke har megen tid tilovers, inden dagen er omme. Mange af de adspurgte børns udsagn vidner om stillesiddende familieaktiviteter, hvor man enten spiller kort eller i fællesskab løser de huslige pligter. Flere børn beskriver familiesamvær som noget, der i højere grad er forbundet med hjemlig hygge end fysiske aktiviteter; turene går til Blockbuster eller rundt om søerne. Om sommeren er familierne dog mere aktive. Mange af dem tager til stranden for at nyde sol og vand eller i Valbyparken for sammen $\mathrm{fx}$ at spille fodbold, spise og lege.

Travlheden i hverdagen synes at afholde familien fra de mere fysiske udfoldelser. Et barn fortæller om en travl hverdag med en nyfødt lillesøster. Et andet barns far har for travlt, og hans mor bor for langt væk til at kunne støtte ham i fysisk aktivitet i det daglige.

"Hvis min far ikke havde fået en knæskade, og jeg ikke lige havde fået en lillesøster, så tror jeg, at han gerne ville gå med ned og skøjte, han har travlt, det kører lidt sammen det hele nu"

(N, pige 5. kl., VNS, fokusgruppeinterview, 20-01-2010)

"Mine forældre er skilt, og min far har ret travlt, og min mor bor rigtig langt væk i Vejle, så hun har ikke tid, men vi går tit i biografen ... vi går også tit en tur i Blockbuster"

(A, dreng, 5. kl., VNS, fokusgruppeinterview, 20-01-2010)

Andre børn beretter om en tilsvarende tendens, hvor familiesamværet foregår som stillesiddende hjemlig hygge omkring et spil kort frem for gåture eller anden fysisk aktivitet. Følgende citater giver et indblik i, hvad børn laver med deres familier i fritiden:

"Vi spiller kort, vi spiller meget Uno"

(R, dreng 2. kl., ØS, fokusgruppeinterview, 27-01-2010)

"Nogle gange tager vi i svømmehallen, og vi laver ikke så meget mere"

(K, pige 2. kl., ØS, fokusgruppeinterview, 27-01-2010)

"Hjemme hos mig må man ikke lave så meget og larme så meget"

(L, pige 2. kl., ØS, fokusgruppeinterview, 27-01-2010)

Citaterne illustrerer, at børnene med deres familie ofte spiller forskellige brætspil eller vælger andre stillesiddende aktiviteter inden for hjemmets rammer.

Nogle familier fortæller, at de går søndagsture i henholdsvis Enghaveparken og langs søerne eller cykler ture på Vestamager. Familien, der går søndagstur i Enghaveparken, ser på fugle og ænder 
og spiller fodbold sammen (se foto 26 og 27). Familien, der går søndagstur langs søerne, ser på fugle, ænder og andre mennesker (se foto 28 ).

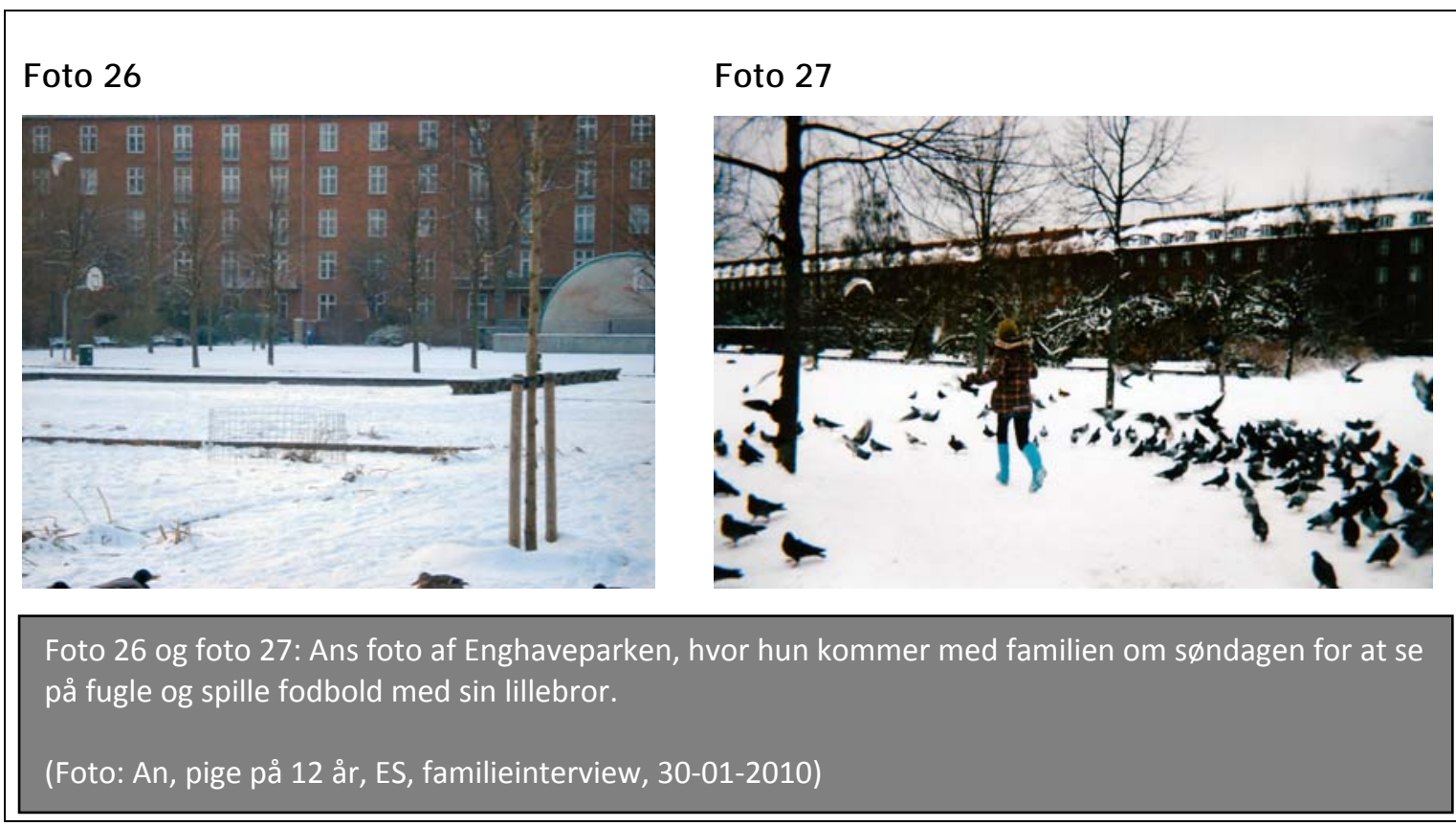

\section{Foto 28}

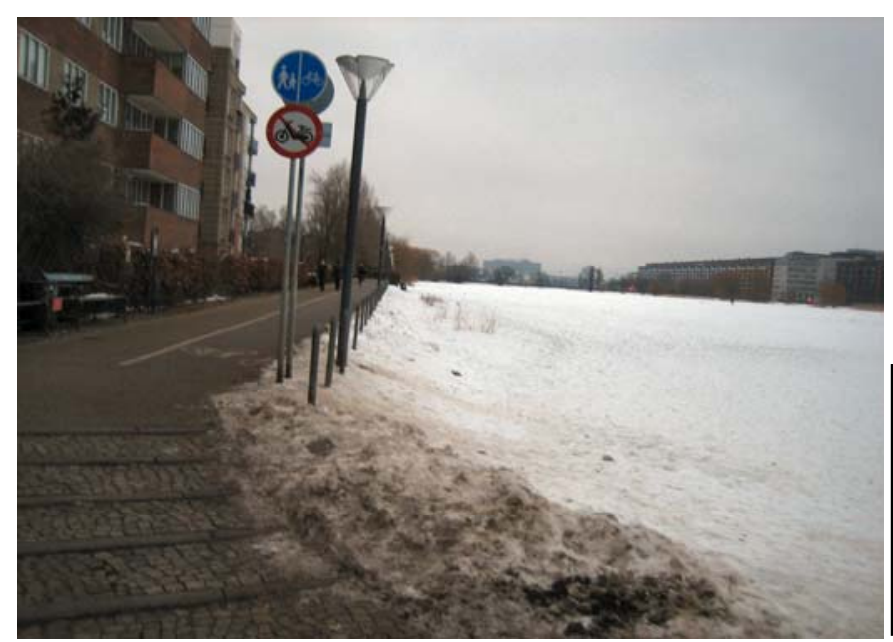

Foto 28: J's foto af søndagsudflugt med familien langs søerne.

(Foto: J, pige på 12 år, $\varnothing \mathrm{S}$,

Familieinterview, 11-02-2010)

Børnenes udsagn $\mathrm{i}$ interviewene vidner om, at deres fysiske aktiviteter primært foregår $\mathrm{i}$ en relation med andre børn og ikke i særlig høj grad sammen med deres familier. Familierne giver udtryk for, at de mangler tid og overskud til at foretage fysiske aktiviteter sammen. Flere af disse familier fortæller samtidig, at de måske bedre ville kunne overkomme at deltage i nogle fysiske aktivitetstilbud, hvis de ikke selv skulle stå for planlægningen af dem. 


\section{Skolemæssige forpligtelser}

Flere af børnene mener ikke, at deres skolemæssige eller huslige pligter er en barriere for deres fysiske aktivitet i det daglige, hvilket nedenstående citater illustrerer:

"Nej, jeg har ikke, jeg går kun ned med skraldespanden"

"Hvad med lektier?"

(N, dreng 5. kl., VNS, fokusgruppeinterview, 13-01-2010)

"Nej, jeg laver det for det meste i skolen" (interviewer)

"J eg har ikke rigtigt pligter"

(N, dreng 5. Kl., VNS, fokusgruppeinterview, 13-01-2010)

"Så I har gode muligheder for at dyrke sport?"

(B, pige 5. kl., VNS, fokusgruppeinterview, 13-01-2010)

"Ja"

(interviewer)

(N, dreng 5. kl., VNS, fokusgruppeinterview, 13-01-2010)

Børnene mener, at de har gode muligheder for at deltage i foreningsidræt og til selv at organisere spil ol. i deres fritid; de har ikke så mange lektier, de skal lave i fritiden, og de har ikke så mange huslige pligter hjemme.

Alligevel viser interviewene, at børnene ofte føler sig trætte og uoplagte efter en skoledag, som derfor får en mere indirekte indflydelse på deres fysiske udfoldelser i hverdagen, hvilket ses af svarene nedenfor:

"Er der nogen gange, hvor I føler jer for trætte til at lave noget?"

"Ja"

(interviewer)

"J a"

(A, dreng 5. kl., VNS, fokusgruppeinterview, 20-01-2010)

(B, pige 5. kl., VNS, fokusgruppeinterview, 20-01-2010)

"Skolen, man har været tidligt oppe, og så er man træt"

(P, pige 7. kl., TDS, fokusgruppeinterview, 20-01-2010)

"Og så efter skole lige når man kommer hjem, så er det ligesom man besvimer, man kan ikke noget"

(Pi, pige 5. kl., TDS, fokusgruppeinterview, 20-01-2010)

Nogle af børnene beretter om, hvordan de bevidst arbejder med sig selv for at inkludere den fysiske aktivitet i deres hverdag, på trods af at de faktisk føler sig uoplagte: 
"J a, efter skole, nogle gange gider jeg ikke rigtig, når først jeg er kommet hjem, og så skal ud igen med vennerne ... hvis jeg siger nej, hvis jeg vænner mig for meget til at sige nej, så vil jeg jo gøre det hele tiden, så jeg lukker mig inde i en boble og laver ikke noget, så jeg tager mig sammen, men nogen gange kan jeg ikke. Hvis jeg siger nej én gang, så aftaler jeg med mig selv, at så skal jeg sige 'ja' næste gang, for jeg synes ikke bare, at jeg skal sidde og gå på pc"

(N, dreng 5. kl., VNS, fokusgruppeinterview, 20-01-2010)

Denne drengs beskrivelse vidner om en høj grad af refleksiv forståelse af sine reaktionsmønstre. Han er bevidst om, at hans træthed kan afholde ham fra fysisk aktivitet og samvær med andre, og han handler for at imødegå et usundt - og for ham uacceptabelt - mønster, hvor hans fysiske aktivitet vil mindskes pga. manglende overskud efter en skoledag.

Andre børn oplever, at de af og til må vælge mellem fysisk aktivitet - særligt den selvorganiserede - og lektielæsning i hverdagen. Citaterne nedenfor vidner om et hverdagsligt og tilbagevendende dilemma, men giver også indblik i, hvordan børnene reflekterer, handler og organiserer sig for at overkomme dette dilemma.

"J a, hvis man skal lave lektier"

(P, pige, 7. kl., TDS, fokusgruppeinterview, 20-01-2010)

"Eller hvis man har lektier, så siger ens mor, at man skal være hjemme"

( $P$, pige, 5. kl., TDS, fokusgruppeinterview, 20-01-2010)

"J a, fx i dansk har vi for mange lektier, så må man gå hjem og lave lektier inden badminton og droppe klubben, lade være med at går derned og spille"

(S, dreng 6. kl., TDS, fokusgruppeinterview, 20-01-2010)

Det ser også ud til, at børn føler sig meget forpligtede i forhold til deres skolearbejde, der i må gå forud for fysisk aktivitet. Det er muligvis også en prioritering, som deres forældre ønsker og anerkender.

\section{Trosmæssige og familiemæssige forpligtelser}

Børns trosmæssige og familiemæssige forpligtelser synes at udgøre en begrænsning i forhold til deres mulighed for fysisk aktivitet i hverdagen. En mindre gruppe af de interviewede af anden etnisk oprindelse end dansk giver udtryk for, at de ikke har tid og overskud til fysiske aktiviteter pga. sådanne forpligtelser. Det gælder særligt pigerne, idet de har en del pligter af huslig art i hjemmet, og fordi de skal bruge en del tid på at gå til koranskole i hverdagen. 


\section{Foto 29}

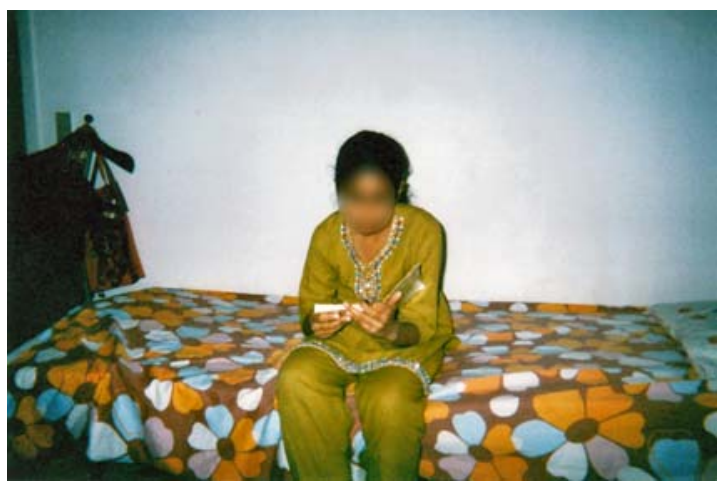

An har taget foto af hende selv, når hun øver sig i koranlæsning. Dette fylder en del af hendes tid, hvorfor hun heller ikke føler, hun har så megen tid til fysiske aktiviteter.

\section{(Foto: An, pige på 11 år, ES, familieinterviews, 30-01-2010)}

Denne gruppe af piger giver direkte udtryk for, at pligterne skaber en kønsmæssig ulighed i relation til den tid, der er til rådighed og derfor deres mulighed for at deltage i faste, organiserede fysiske aktiviteter i hverdagen. Drengene har ikke nær så mange pligter i hjemmet og har derfor bedre mulighed for at gå til de aktiviteter, de har lyst til.

"I har ikke så meget tid, fordi I hjælper meget, hvad er det I hjælper med?"

"Passe børn"

(Y, pige, 5. kl., ES, fokusgruppeinterview, 11-01-2010)

"Vaske op, støvsuge, gøre rent, gøre rent inde på værelser"

(Y, pige, 5. kl., ES, fokusgruppeinterview, 11-01-2010)

"Køber I også ind?"

"J a, rigtig meget"

(interviewer)

(A, pige, 5. kl., ES, fokusgruppeinterview, 11-01-2010)

"Men drengene de har rigtig meget tid, fordi de jo ikke hj ælper derhjemme og sådan, fordi de er drenge, men min lillebror går til sport han går til kung fu, drenge har mere tid end piger til at gå til noget"

(A, pige, 5. kl., ES, fokusgruppeinterview, 11-01-2010)

To piger fortæller, at de går i koranskole op til seks dage om ugen efter normal skoletid. Derfor har de ikke tid til fysisk aktivitet, hverken i de organiserede idrætstilbud eller til at bruge 
mulighederne for selv-organiseret spil og leg i egne gårde eller i nærmiljøet. Citatet nedenfor illustrerer dette:

"Kan du godt lide at spille bold og sådan noget?"

"J eg kan godt lide at spille basket"

(interviewer)

"Har du så prøvet at gå til det eller?"

(Af, pige, 5. kl., VNS, fokusgruppeinterview, 20-01-2010)

"... jeg gik i 5. kl., men så havde jeg ikke tid og så stoppede jeg"

(interviewer)

(Af, pige, 5. kl., VNS, fokusgruppeinterview, 20-01-2010)

"Fordi jeg også skulle gå til koran, og det var også i hverdagene, så jeg havde ikke tid ... Vi har fri ved 14-tiden og der gik det også i gang, så jeg havde ikke tid"

(Af, pige, 5. kl., VNS, fokusgruppeinterview, 20-01-2010)

"Man bliver træt så, så skulle jeg i skole og så hjem og så til koranskole og så til basket, det var irriterende, så bliver man træt"

(Af, pige, 5. kl., VNS, fokusgruppeinterview, 20-01-2010)

Pigerne har altså tidligere haft lyst til og også været engagerede i organiseret idræt, men oplever nu, at de hverken har tid eller overskud til fysiske aktiviteter pga. huslige og trosmæssige forpligtelser. Denne mindre gruppe af piger synes - ved både at have huslige og trosmæssige pligter - at være særligt udsatte for træthed og mangel på overskud til fysisk aktivitet. Det ser desuden ud til, at kulturelle normer spiller en rolle.

"Vi er pakistanere, vi gør ikke som de andre børn, vi er sådan hjemme og passer vores hus og hjælper vores mor og er søde, fordi de er søde mod os og gør noget for os som børn, og så skal vi også gøre noget for dem jo og vi prøver sådan at hjælpe, laver lektier, vi har ikke tid til noget"

(T, pige, 5. kl., ES, fokusgruppeinterview, 11-01-2010)

De kulturelle normer ser ud til at skabe en gensidig forventning om, at piger - i højere grad end drenge - bidrager til hjemmets husholdning, men også tilbringer mere tid hjemme for på den måde at gøre deres familier glade og leve op til forventningen om 'den gode pige', hvilket nedenstående citat vidner om: 
"J a, på en måde, for de er meget glade for, at man er hjemme og er en god pige og sådan, så er de rigtig glade"

( $T$, pige, 5. kl. ES, fokusgruppeinterview, 11-01-2010)

"Så selvom man har lyst, så er det også vigtigt at gøre sin familie glad?"

(interviewer)

"Nej altså, men hvis man er sådan hjemme, så bliver de glade, men hvis vi siger, man har så ikke så meget tid til at gå til sådan noget sport, fordi man er hjemme og sådan noget og så vil de sikkert sige, for vi er jo pakistanere, og vi gør ikke det samme som alle mulige andre muslimer gør, vi skal være hjemme, så det er der ikke tid til"

(T, pige, 5. kl., ES, fokusgruppeinterview, 11-01-2010)

Selvom familien ikke forbyder pigerne at gå til idræt eller være fysisk aktive i hverdagen, føler disse piger alligevel, at det ikke er acceptabelt at bede deres familier om lov. De kulturelle normer ser ud til at begrænse pigerne i deres tro på selv at kunne skabe rum for fysisk aktivitet $\mathrm{i}$ hverdagen. Dette står i kontrast til de andre interviewede børns oplevelse af deres muligheder for fysisk aktivitet i forhold til eventuelle begrænsninger relateret til familiemæssige forpligtelser og ressourcer, hvilket nedenstående citat illustrerer:

"Hvad med jeres familie, har de nogensinde sagt til jer, at det kunne I ikke gå til eller?"

"Nej"

(interviewer)

"Nej"

(D, dreng, 7. kl., ES, fokusgruppeinterview, 11-01-2010)

"I får altid lov?"

(P, pige 7. Kl., ES, fokusgruppeinterview, 11-01-2010)

"Ja"

(interviewer)

(P, pige, 7. kl., ES, fokusgruppeinterview, 11-01-2010)

Økonomiske ressourcer ser ikke umiddelbart ud til at være en hindring for, at børnene kan deltage i organiserede idrætsaktiviteter. De giver udtryk for, at de altid for lov til at deltage i aktiviteter, selv om det indebærer en udgift.

"Så I får altid lov selvom det koster penge?"

(interviewer)

"Ja"

(P, pige, 7. kl., ES, fokusgruppeinterview, 11-01-2010)

"Ja"

(D, dreng, 7. kl., ES, fokusgruppeinterview, 11-01-2010) 
Nogle af børnene giver til gengæld udtryk for, at der er en sammenhæng mellem at passe sine skolepligter og andre aktiviteter og at få lov til at gå til en ønsket idrætsaktivitet. Hvis blot de passer deres skole mm., får de også lov til at gå til de aktiviteter, som de har lyst til. Dette synes også at have været tilfældet for den mindre gruppe af piger af anden etnisk oprindelse end dansk, før de blev forpligtede af engagementet i koranskolen.

"Nej, det siger mine forældre slet ikke, de siger, at hvis jeg passer skolen og går til musikskolen, hvis jeg husker at gå til klaver, så må jeg gerne gå til fodbold"

(Y, dreng, 5. kl., VNS, fokusgruppeinterview, 20-01-2010)

Enkelte piger har oplevet ikke at få lov til at deltage i specifikke idrætsformer som fx boksning. Her drejer det sig oftest om, at deres familie - og særligt mødrene - ikke anerkender idrætsformen/sportsgrenen, eller de er bekymret for, at børnene skal komme til skade:

"Ja, jeg ville gerne gå til boksning, men måtte ikke"

(E, pige, 4. kl., ØS, fokusgruppeinterview, 27-01-2010)

"Arhhjj, det ville jeg også, men måtte heller ikke"

(J, pige, 6. kl., ØS, fokusgruppeinterview, 27-01-2010)

"J eg tror måske godt, jeg må, min mor vil ikke have det, men min far synes, det er o.k."

(E, pige, 4. Kl., ØS, fokusgruppeinterview, 27-01-2010)

"Min mor synes, de fleste boksere er dumme i hovedet, så ..."

(J, pige, 6. Kl., ØS, fokusgruppeinterview, 27-01-2010)

Noget tyder på, at det i en travl hverdag kan være svært for forældre og børn at få organiseret et fælles samvær omkring fysisk aktivitet. Det ser desuden ud til, at børn ligeledes føler, at deres hverdag er fuld af forpligtigelser af skolemæssig art og for nogen også af trosmæssig karakter. De føler sig generelt trætte efter endt skoledag, og mange må derfor organisere sig for at skabe rum og mulighed for fysisk aktivitet i deres hverdag. Af og til må de prioritere lektier frem for fysiske udfoldelser. Tid og overskud synes således at være en væsentlig faktor, når det handler om både børns og deres familiers aktuelle og ønskede fysiske aktivitet $\mathrm{i}$ hverdagen. 


\section{Opsamling og konklusion}

Rapporten præsenterer resultaterne af børns og familiers oplevelser af og syn på deres muligheder for fysisk bevægelse på Vesterbro, italesat i sprog og billeder. Resultaterne giver tilsammen et nyt og interessant indblik i, hvad der hindrer og fremmer børns og deres familiers fysiske aktivitet. Gennem en analyse af børns og deres familiers opfattelse af muligheder for henholdsvis organiserede idrætstilbud, selv-organiserede fysiske aktiviteter såsom spil af forskellig slags og selv-organiseret leg frembringes perspektiver på hvilke behov og muligheder, der kan være i fokus for fremtidige tiltag på Vesterbro.

\section{Organiseret idræt og selv-organiserede fysiske aktiviteter på Vesterbro}

Undersøgelsen viser, at børn og deres familier generelt er tilfredse med udbuddet af organiserede idrætstilbud. De oplever, at Vesterbro besidder et stort udbud af aktivitetsmuligheder, men nogle børn og deres forældre efterlyser bedre mulighed for at gennemskue det store udbud af tilbud. De organiserede idrætstilbuds strukturerede form ser ud til at passe børnene godt. De giver udtryk for stor tilfredshed med den strukturerede form, særligt når de oplever, at instruktørerne giver dem mulighed for at tilegne sig sporten på en anerkendende og hensynsfuld måde.

Børns selv-organiserede fysiske aktiviteter foregår både på (lege)pladser, parker og i private gårdmiljøer. Undersøgelsen viser, at der er en utryghed forbundet med de offentlige steder på grund af bydelens misbrugs - og prostitutionsmiljø og visse grupper af unge. Det er dog primært efter mørkets frembrud, at børn og deres familier føler sig utrygge. Denne utryghed influerer på deres hverdagsliv, idet flere af dem nævner, at der er steder, de ikke tør passere, når de skal hjem fra deres fritidshjem, klub ol. De selv-organiserede lege og spil foregår desuden i høj grad i de private gårde. Her føler børnene sig trygge, fordi de kender de voksne og de andre børn. Forældre er ligeledes trygge ved deres børns ophold $\mathrm{i}$ gårdene, fordi de fleste af gårdene er aflåste, således at kun beboerne kan opholde sig der.

\section{Potentialer og barrierer}

Vesterbros legepladser, parker og andre pladser beskrives på en gang som offentlige områder, der skaber stor legeglæde for børn og familier i deres hverdag, og som steder, hvor det opleves utrygt at opholde sig, og dette får dem til at fravælge visse områder. Børn og familier på Vesterbro fravælger områder, der opfattes velegnede til fysisk aktivitet, pga. utryghed eller decideret frygt for områdernes misbrugsmiljø eller mistanke om kriminalitet. Nogle er bange for alle de offentlige steder på Vesterbro, andre kun for nogle få udvalgte områder, men alle udviser utryghed $i$ en eller anden grad. De fleste er kun bange om aftenen, idet de mener, at Vesterbro ændrer sig mærkbart efter mørkets frembrud. Denne frygt ser ud til i få tilfælde at bunde i personlige 
og konkrete ubehagelige oplevelser, men i de fleste tilfælde ser den ud til at relatere sig til socialt konstruerede fordomme om områdets miljø.

Gårdmiljøerne på Vesterbro ser ud til at skabe et trygt rum for at børn og deres familier kan organisere spil og leg i hverdagen. Det er en tryghed, de ikke kan genfinde i de offentlige parker og på bydelens (lege)pladser.

\section{Samspil mellem rum og aktiviteter}

Gårdenes aflukkede rum ser ikke bare ud til at skabe større tryghed for børn og deres familier, men gårdenes mindre organiserede rum ser også ud til at åbne for kreativ leg på samme måde som gør sig gældende for områdets offentlige parker. Denne undersøgelse viser, at der tilsyneladende ligger et helt særligt potentiale i gårdenes mindre organiserede rum, hvor børn kan føle sig trygge og samtidig har mulighed for at udfolde sig kreativt. En mindre gruppe af piger med anden etnisk baggrund udtrykker særlig stor tilfredshed med gårdenes nære og trygge rum og rammer, idet disse børn synes at have særlig mange forpligtelser i hjemmet, hvilket gør det svært for dem at deltage i organiserede idrætsaktiviteter. Denne gruppe af piger ser desuden ud til at have tidskrævende trosmæssige forpligtigelser. Gruppen kunne derfor drage fordel af, at man i DGI-byens Go Active-projekt søger at etablere dialog med familier og deres trossamfunds foreninger og organisationer for at fremme gruppens muligheder for at være fysisk aktive i hverdagen. Generelt for alle de interviewede børn er det, at de nævner træthed grundet skolegang og skolemæssige pligter, som den største barriere for fysiske aktiviteter. På den baggrund kunne det være interessant og givende at etablere et tæt samarbejde med skolerne med henblik på at få integreret fysisk aktivitet i børns skoledag. Dette kunne imødegå den nærmest 'mentale træthed', der ifølge børnene netop er den, der hæmmer dem i forhold til deres aktuelle og ønskede fysiske aktivitet i hverdagen.

Undersøgelsen viser også, at der er et særligt potentiale i gårdmiljøernes lege og andre fysiske aktiviteter. I gårdene udfolder børnene sig aktivt trods deres træthed og mangel på overskud. Gårdenes trygge rammer og mindre kodede rum ser ud til at kunne åbne for et fokus på alternative og selv-organiserede måder at bevæge sig på. Børnene viser sig som aktive medskabere af både rum og aktiviteter, da de fx ved hjælp af medbragte objekter organiserer både traditionelle lege som gemmelege, fangelege og dåseskjul, men også nye og mere utraditionelle lege, der udgør et stærkt potentiale til en udvikling af alternative tilbud til børn og unge i bydelen. Således viser undersøgelsen, at man ved at inddrage børn vil kunne skabe alternativer, der kunne indfange hele gruppen af børn - udsatte såvel som ikke-udsatte - på Vesterbro. Undersøgelsen viser endvidere, at tilstedeværelsen af voksne er af afgørende betydning for børns tryghed. En del af børnene vil finde det betryggende med flere voksne på de i rapporten omtalte offentlige pladser. 


\section{Rum, aktiviteter og børns deltagelse}

Med baggrund i undersøgelsens resultater kunne der ligge potentialer i enten at tage udgangspunkt i områdets gårde eller $\mathrm{i}$ at konstruere tilsvarende alternative trygge rum, hvor de utrygge elementer $\mathrm{fx}$ misbrugere fra Vesterbro holdes ude. Her kunne børn uden frygt skabe og udfolde deres fysiske aktiviteter. Det kunne således være interessant at tage udgangspunkt i børns egne evner til at skabe rum og rammer, der synes at tilfredsstille dem i deres leg: Tilbud skabt af børn selv og rettet mod børn.

I 2004 foretog Ingelise Flensborg, lektor på DPU, en undersøgelse af skolegårde på Vesterbro, ligeledes ud fra begrebet 'omgangskvaliteter', hvori elevers opfattelser af rums funktionalitet og brugbarhed for forskellige aktiviteter blev analyseret (Flensborg, 2009). I undersøgelsen konkluderer hun bl.a., at elevers evne til at tænke nyt og kreativt omkring de rum, de indgår i, er meget begrænset, hvilket forklares med, at elever er socialiseret ind $\mathrm{i}$ et bestemt sæt af koder og ritualer for det at danne skole.

I sammenligning med Flensborgs (2009) resultater er det derfor spændende og værd at bemærke, at undersøgelsen her viser, at børn uden for skolen skaber mange og gode initiativer til at ændre på de organiserede rum, som de indgår i, eller selv konstruerer rum, der adskiller sig fra det bestående. Undersøgelsen viser, at de rum, der ikke på forhånd er så gennemorganiserede, såsom parkerne og til dels gårdene, også er de rum, hvor det er lettest for børn at tænke kreativt og få mulighed for at skabe de mest kreative lege og rum. Særligt to børns (M og Al) kreative lege vidnede om, at der er potentialer her, idet de fremviste og tydeliggjorde børns naturlige kompetencer til at skabe optimale samspil mellem deres leg og valg af rum (se foto $23 \mathrm{og}$ foto 24).

Undersøgelsen kan på denne måde bidrage med ny viden om, hvorledes vi kan tænke rummet ind som en pædagogisk faktor, der kan være med til at give børn og deres familier rum og rammer for kreativ fysisk bevægelse, hvor der både er plads til, at børns egne selvskabte lege kan skabes og udvikles, og hvor familier kan få mulighed for at skabe trygge rum for samvær. Børnenes kulturelle forforståelse bliver tydelig i deres valg af fysiske rum og aktiviteter. Når de tager billeder af de organiserede rum, $\mathrm{fx}$ af offentlige legepladser, er aktiviteten som forventelig: De gynger, spiller bold eller klatrer på etablerede klatrevægge eller -stativer. Når de derimod tager billeder af mindre organiserede rum, såsom parker og gårde, er der pludselig billeder af mere uforudsigelige aktiviteter, som fx en selvkonstrueret kælkebakke (se foto 24). Rums kulturelle medbetydninger er, som Ingelise Flensborg også udtrykker det, allerede indbygget i børns kulturelle forforståelse, hvilket betyder, at et organiseret rums rammer er svære at bryde ned. Derfor kan vi lære meget af de mere uorganiserede rum og børns umiddelbare og ikke forudindtagede måde at indtage og anvende dem på - og ligeledes medtænke Flensborgs (2009) pointe med 
skolesocialiseringens betydning for børns opfattelse af rum i eventuelle nye tiltag for at imødegå børns mentale træthed og fremme fysisk aktivitet i skoletiden.

Undersøgelsen bidrager altså med ny viden, der kan inspirere og danne grundlag for etablering af nye alternative tilbud iværksat af DGI-byens børne- og ungeprojekt Go-Active. På længere sigt kan denne viden også anvendes som inspirationskilde til andre fysiske aktivitetstilbud og sundhedsfremmende tiltag i lignende lokalområder.

\section{Børns sundhedsfremme på Vesterbro}

På baggrund af undersøgelsens resultater synes der at være en tydelig sammenhæng mellem børns og deres familiers hverdag med skolemæssige, arbejdsmæssige, hjemlige og trosmæssige pligter og deres fysiske aktivitet.

I en holistisk sundhedsfremmende optik betyder det, børns og familiers sundhed i sidste ende vil påvirkes af disse kulturelle og samfundsmæssige forhold. Børnenes udtalelser vidner om, at de ofte må navigere mellem ønsket om at være fysisk aktive og at opfylde deres skolemæssige forpligtelser; forpligtelser, der oftest går forud for leg, spil og andre fysiske udfoldelser.

Derfor synes det hensigtsmæssigt at inddrage børn og familier, men også skolerne, i planlægningen af nye tiltag i forbindelse med DGI-byens børne og ungeprojekt Go-Active. Det kunne være gavnligt at inddrage skolerne for at få koblet læring med fysiske bevægelsestilbud, der kan dæmme op for børns udtalte mentale træthed efter endt skoledag. Dette kunne gøres ved at konstruere læreprocesser, der kan skabe forståelse for Iæring som en mental og kropslig proces. Hertil synes rollespillets form og opbygning at være et godt bud på, hvordan faglighed og fysisk aktivitet kan kombineres. I skoleregi må rollespillene derfor tage udgangspunkt i folkeskolens formål og faglige mål og ikke i rollespillets traditionelt legende fortællinger.

Rollespillets form og struktur synes desuden at give rig mulighed for ægte, aktiv deltagelse, hvor børn ikke bare opnår en vis grad af medbestemmelse i læreprocessen, men hvor de bliver aktive skabende konstruktører af spillets fælles fortælling og deres egen individuelle spilleproces. På samme måde kan vi forstå børns deltagelse i en læreproces og se dem som aktive deltagere, der i et samspil skaber undervisningstilbuddet og den enkeltes individuelle lærdom. Det er en forståelse af aktiv inddragelse, der genfindes i kritisk sundhedspædagogik, der med udgangspunkt i et positivt og bredt sundhedsbegreb lægger vægt på ægte deltagelse (Simovska, 2006) som en særlig faktor, der bidrager til børns motivation, ej erskab og lyst til at tage ansvar for egen og andres sundhed (J ensen, 1997 og Simovska, 2006). 
På baggrund af undersøgelsens resultater kan følgende forhold være interessante at tage i betragtning ved konstruktion af fremtidige tilbud om fysisk bevægelse på Vesterbro: Samspil mellem rum og aktivitet, samspil mellem læring og kropslig fysisk aktivitet og involvering som ægte deltagelse.

\section{Perspektiver: Hvor fører det hen?}

Undersøgelsen peger på en række faktorer, der bør tages i betragtning ved kommende tiltag. Følgende faktorer bør man have øje for, ved etablering af fysiske aktiviteter for børn på Vesterbro:

\section{Tryghed:}

- At skabe gode samspil mellem rum og aktiviteter, hvor tryghed er i fokus, svarende til gårdenes trygge atmosfære og med en vis form for voksenstøtte og styring, uden at det ender i for megen kontrol og overvågning.

\section{Involvering:}

- At skabe rum og rammer for, at børn kan deltage aktivt i planlægningen og udførelsen af den fysiske aktivitets indhold og form, dvs. både rumlige, men også sociale og kulturelle rammer for børns kompetence til at være aktive medskabere af frugtbare sammenhænge mellem rum, leg og spil.

Tid:

- At tage hensyn til børns mange opgaver og aktiviteter i hverdagen, fx skole- og familiemæssige pligter. Der må tages høj de for koranskolers og foreninger der ikke er relateret til fysisk aktivitets arrangementer og mødetider, hvis børn der er engageret her, skal have bedre mulighed for at være fysisk aktive. Generelt bør der tages hensyn til børns oplevelse af træthed efter endt skoledag. En inddragelse af bydelens skoler i kommende fysiske aktivitetstilbud kunne derfor være interessant, også i forhold til at undersøge muligheden for at koble læring med fysisk aktivitet. 


\section{Referencer}

Flensborg, I. (2009) Omgangskvaliteter. Krop, kultur og kundskaber, Cursiv 4, 2009.

Gibson, J J . (1979) The ecological approach to visual perception, Boston: Houghton Mifflin.

J ensen, B. B. (1997) A case of two paradigms within health education I: Health Education Research. Theory and Practice, vol. 12, nr. 4, s. 419-428.

J ensen, B. B. (2009) Et sundhedspædagogisk perspektiv på sundhedsfremme og forebyggelse I: Carlsson, M., Simovska, V., J ensen, B. B. (red.) Sundhedspædagogik og Sundhedsfremme, teori, forskning og praksis, Aarhus, Aarhus Universitetsforlag, s. 11-29.

J ustiniano, B.(2009) Somaæstetisk blik på undervisningsiscenesættelser - et epistemologisk og didaktisk eksperiment, ph.d.-afhandling, Danmarks Pædagogiske Universitetsskole, Aarhus Universitet.

J ustiniano, B. (2009) Krop, rum og læring: Sundhed I: Carlsson, M., Simovska, V., J ensen, B. B. (red.) Sundhedspædagogik og sundhedsfremme: teori, forskning og praksis, Aarhus: Aarhus Universitetsforlag, s. 175-193.

Morrow, V. (2004) Children's "Social Capital": Implications for Health and Well-being, I: Health Education, vol. 104, nr.4, s. 211-225.

Rasmussen, J. (2002) Textual interpretation and complexity - radical hermeneutics. Paper at The American Educational Research Conference (AERA SIG), Chaos \& Complexity. April 1-5, 2002. New Orleans, USA: AERA.

Rasmussen, J . (1999). Læring og undervisning. Århus: Kvan 54. årg. 19. s. 19-48.

Simovska, V. (2005) Participation and learning about health I: Clift, S., Jensen, B. B. (red.) The health promoting school: International advances in theory, evaluation and practice, Copenhagen, Danish University of Education Press: on behalf of the European Network of Health Promoting Schools, p. 173-193.

Simovska, V. (2006) Case study: Children and young people's voices in health matters - learning by making a difference, WHO/ HBSC Forum 2006, Florence, Italy.

Simovska, V. J ensen, B. B., Carlsson, M. and Albeck. C. (2006) Shape Up: Kurs mod børns og unges deltagelse i sundhed, Barcelona, PAU Education.

Simovska, V. (2007) The changing meanings of participation in school-based health education and health promotion: the participants' voices I: Health Education Research, vol. 22, nr. 6, s. 864-878.

World Health Organisation (1986) Ottawa Charter for Health Promotion. First International Conference on Health Promotion, Ottawa 17.-21 November, Copenhagen: WHO Regional Office for Europe. 